\title{
The JURISDiCTION OF THE Alberta SURFACE Rights BOARD UNDER SECTION 30 OF THE SURFACE RIGHTS ACT
}

\author{
SARAH NYKOLAISHEN AND NIGEL BANKES*
}

This article examines the jurisdiction of the Surface Rights Board of Alberta to award damages under section 30 of the Surface Rights Act. Section 30 provides owners and occupiers with a statutory cause of action for losses or damages caused to their lands through the activities of an operator.

In examining and contrasting jurisprudence under section 30 of the Surface Rights Act with common law tort causes of action, the authors opine that while section 30 does not prevent an owner or occupier from bringing a tort action in relation to loss or damage, a tort action may not be a viable option. The authors therefore propose that in particular situations, section 30 of the Surface Rights Act provides an alternative cause of action through which an owner or occupier may seek damages. The article concludes by finding that section 30 possesses a lower threshold regarding the elements of the cause of action as well as the issue of causation in comparison to common law tort causes of action.
Cet article examine la juridiction du Conseil des droits de surface de l'Alberta dans l'octroi de dommages-intérêts en vertu de l'article 30 de la Loi sur les droits de surface. L'article 30 stipule que le propriétaire ou l'occupant 30 ont un motif d'action légal en cas de pertes ou de dommages causés à leurs terres par les activités d'un exploitant.

$L$ 'article examine la jurisprudence du Conseil en vertu de l'article 30 de la Loi sur les droits de surface et le compare au motif d'action de la common law pour responsabilité délictuelle. $L$ 'auteur fait valoir que l'article 30 n'empêche pas un propriétaire ou un occupant d'intenter une action pour responsabilité délictuelle en cas de perte ou de dommage, mais propose plutôt un motif d'action de rechange. Cet article conclut que l'article 30 définit un seuil inférieur pour établir le motif et les autres éléments de l'action par rapport aux motifs d'action apparenté de responsabilité délictuelle de la common law.

\section{Table of Contents}

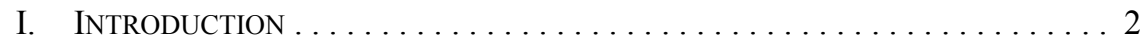

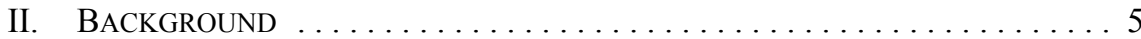

III. THE BOARD'S JURISPRUDENCE $\ldots \ldots \ldots \ldots \ldots \ldots \ldots \ldots \ldots \ldots$

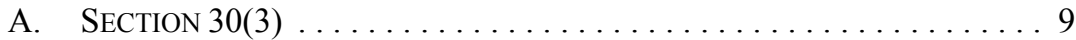

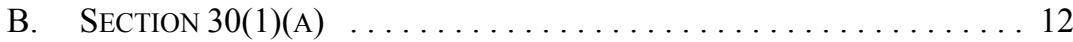

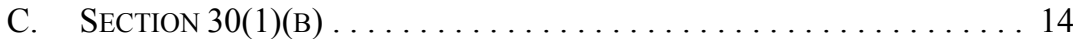

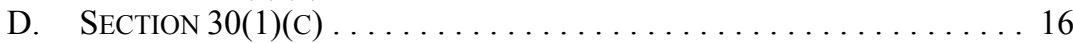

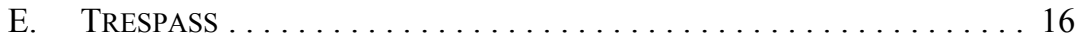

F. Proof of Damage and CAUSATION $\ldots \ldots \ldots \ldots \ldots \ldots \ldots$

G. The NATURE of Liability UNDER Section $30 \ldots \ldots \ldots \ldots$

IV. COMMON LAW Tort CAUSES of ACtion $\ldots \ldots \ldots \ldots \ldots \ldots \ldots \ldots$

A. COMPARING SECTION 30 AND

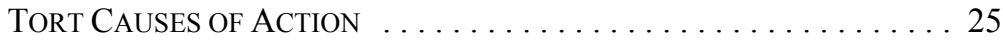

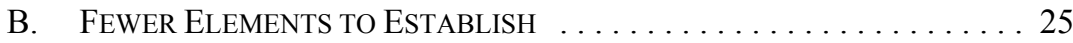

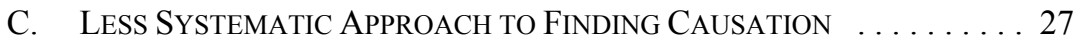

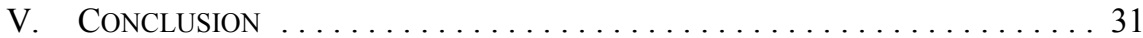

Sarah Nykolaishen, JD candidate (2012), University of Calgary, sarahnykolai@ucalgary.ca and Nigel Bankes, Professor of Law, University of Calgary, ndbankes@ucalgary.ca. Thanks to Lars Olthafer for his comments on an earlier draft of this article. Funding for the research for this article was provided by ISEEE through a grant from Natural Resources Canada. The discussion of common law causes of action in the final part of the article draws on research completed by Julia Gaunce (JD 2010). 


\section{INTRODUCTION}

This article deals with the jurisdiction of the Surface Rights Board of Alberta (SRB or the Board) under what is now section 30 of the Surface Rights Act. ${ }^{1}$ Section 30 authorizes the Board to award damages to surface owners and occupants for losses suffered as a result of the activities of an operator, beyond the losses that have already been compensated under the terms of a surface lease or under a compensation order fixed by the Board.

The principal role of the Board is to issue right of entry orders and to determine the amount of compensation payable by operators to surface owners and occupants. ${ }^{2}$ The Board may issue a right of entry order to an oil and gas operator or an operator proposing to construct a pipeline, transmission line, or telephone line where the operator has been unable to negotiate a surface lease, pipeline easement or similar right of way agreement. ${ }^{3}$ In order to fix the amount of compensation payable to an owner or occupant, the Board may consider the following factors:

(a) the amount the land granted to the operator might be expected to realize if sold in the open market by a willing seller to a willing buyer on the date the right of entry order was made,

(b) the per acre value, on the date the right of entry order was made, of the titled unit in which the land granted to the operator is located, based on the highest approved use of the land,

(c) the loss of use by the owner or occupant of the area granted to the operator,

(d) the adverse effect of the area granted to the operator on the remaining land of the owner or occupant and the nuisance, inconvenience and noise that might be caused by or arise from or in connection with the operations of the operator,

(e) the damage to the land in the area granted to the operator that might be caused by the operations of the operator, and

(f) any other factors that the Board considers proper under the circumstances. ${ }^{4}$

RSA 2000, c S-24 [SRA].

Ibid, ss 12, 23.

The $S R A$, ibid, s 1(h) defines "operator" as:

(i) the person or unincorporated group of persons having the right to a mineral or the right to work

it, or the agent of such a person or group of persons, [or]

(ii) with reference to a pipeline, power transmission line or telephone line, the person empowered

to acquire an interest in land for the purpose of the pipeline, power transmission line or telephone

line under the Pipeline Act, the Hydro and Electric Energy Act or the Water, Gas and Electric

Companies Act, as the case may be.

Throughout this article "operator" refers primarily to companies responsible for oil and gas well sites.

This reflects the fact that oil and gas well sites give rise to the largest proportion of section 30 claims.

4 Supra note 1, s 25(1). There is a significant amount of case law and commentary on the fixing of compensation orders. Livingston v Siebens Oil \& Gas Ltd (1978), 8 AR 439 (CA), established that great weight should also be given to patterns of voluntary dealings. Dome Petroleum Ltd v Richards (1985), 66 AR 245 (QB) supports the use of a "global approach" to compensation. This approach relies on patterns of dealings and considers the overall effect of the entry without breaking compensation down into different categories. For more discussion on fixing compensation, see Barry Barton, "Controversy in Surface Rights Compensation: Pattern of Dealings Evidence and Global Awards" (1985) 24:1 Alta L Rev 34; William N Richards \& Francis CR Price, "Surface Rights Acquisition and Compensation" (1982) 20:1 Alta L Rev 1. More recently, it has been argued that pipeline surface rights compensation is becoming out of step with expropriation law principles. See Lars Olthafer, "Recent Developments in 
Less well known is the Board's jurisdiction under section 30, a jurisdiction that was first conferred on the Board in 1972. ${ }^{5}$ Section 30 effectively creates a new statutory cause of action and overlaps considerably with common law tort causes of action such as negligence, nuisance, and the rule in Rylands $v$ Fletcher $^{6}$ that are available to owners or occupants in the ordinary courts, including the Provincial Court of Alberta (subject to dollar limits to that court's jurisdiction) and the Court of Queen's Bench of Alberta. The current version of section 30 reads as follows:

Settlement of disputes

30(1) Subject to subsections (2) to (4), the Board may hold proceedings and make an order with respect to a dispute between the operator and an owner or occupant who are parties to a surface lease or the operator and an owner or occupant under a right of entry order as to the amount of compensation payable by the operator

(a) for damage caused by or arising out of the operations of the operator to any land of the owner or occupant other than the area granted to the operator,

(b) for any loss or damage to livestock or other personal property of the owner or occupant arising out of the operations of the operator whether or not the land on which the loss or damage occurred is subject to the surface lease or right of entry order, or

(c) for time spent or expense incurred by an owner or occupant in recovering any of the owner's or occupant's livestock that have strayed due to an act or omission of the operator whether or not the act or omission occurred on the land that is subject to the surface lease or right of entry order.

(2) The Board has jurisdiction to determine a dispute under this section only if

(a) the application is made in writing to the Board by a party to the dispute within 2 years from the last date on which damage is alleged to have occurred,

(b) $\quad \ldots$ and

(c) ... the amount claimed by the owner or occupant does not exceed $\$ 25000$.

(3) This section does not apply to a claim for compensation the amount of which may be determined by the Board under section 25 .

Surface Rights Law - Pipeline Right-of-Way Compensation - Annual Payments and Injurious Affection - Federal and Alberta Developments" (2005) 43:1 Alta L Rev 89. Olthafer refers in this context to Zubick v Corridor Pipeline Ltd, 2002 ABQB 452, 315 AR 274, an appeal from the Board addressing annual compensation for pipeline rights-of-way.

5 Surface Rights Act, SA 1972, c 91 [1972 Act]. The literature referred to above does not discuss this jurisdiction of the Board.

6 (1868), 3 LRHL 330 [Rylands]. 
(4) An order under this section may be appealed by the operator or the owner or occupant as though the order were a compensation order under section $23{ }^{7}$

While recognizing that section 30(1) uses the term "compensation," not "damages," we shall refer the jurisdiction of the Board under section 30 as the Board's "damages jurisdiction" to distinguish it from the Board's principal jurisdiction under what is now section $25 .^{8}$ There is no Hansard record that speaks to the introduction of this new statutory jurisdiction of the Board. However, it seems reasonable to think that the jurisdiction was introduced to provide owners and occupants with speedy access to an informal dispute resolution process and to supplement the jurisdiction of what was then the District Court of Alberta.

The main purpose of this article is to provide an account of the jurisprudence of the Board under this comparatively new head of jurisdiction, and ultimately, to compare the statutory cause of action created by section 30 with common law tort causes of action. ${ }^{9}$ The article

SRA, supra note 1 , s 30 .

The drafter may have elected to avoid using the term "damages" to forestall the argument that the SRB in this context is acting like a section 96 court (Constitution Act 1867 (UK), 30 \& 31 Vict, c 3, s 96, reprinted in RSC 1985, App II, No 5). However, even if section 30 used the term "damages," this would be unlikely to create a serious section 96 issue. Section 30 still would not remove part of the courts' core jurisdiction (to award damages in relation to property damage) or transfer the courts' supervisory jurisdiction to the Board. In no way does section 30 deny an owner or occupant the option of bringing a damages claim against an operator on its land by right of surface lease or right of entry order before the courts instead of the Board. Further, section 30(4) of the SRA grants a right of appeal to owners and occupants and operators "as though the order were a compensation order under section 23." Under section 26(1) of the SRA, a section 23 compensation order may be appealed to the Court of Queen's Bench. Hence, section 30 is unlike the legislation considered in Crevier v Quebec $(A G)$, [1981] 2 SCR 220 in that it does not purport to exclude "the reviewing authority of any other court, whether by appeal or by evocation" (ibid at 239).

There are similar provisions in the surface rights legislation of Saskatchewan and British Columbia. Section 61 of Saskatchewan's Surface Rights Acquisition and Compensation Act, RSS 1978, c S-65 $[S R A C A]$ states that operators are primarily liable to owners and occupants for all tortious acts committed by their employees and contract workers.

"Tortious act" is defined as

a wrongful, injurious or illegal act that results in:

(a) loss or damage to the land of an owner or occupant ... [which has not been] acquired

by an operator; and

(b) any other loss or damage suffered by the owner or occupant arising out of such act (ibid, s 60).

Section 63 of the SRACA contemplates that parties who cannot reach an agreement may apply to the Saskatchewan Board provided that the claim is for less than $\$ 1,000$ (which seems very low). Section 64 shifts the burden of proof in damage claim proceedings such that "evidence of the tortious act complained of is prima facie evidence of the liability of the operator for the tortious act." This provision also applies to "any action at law" (ibid, s 64).

British Columbia's Surface Rights Board (BC Board) is also authorized to hear and address damages claims under the Petroleum and Natural Gas Act, RSBC 1996, c 361, s 163 [PNGA]. As of October 2010, section 163 replaces the earlier section 16 (Energy, Mines and Petroleum Resources Statutes Amendment Act, 2010, SBC 2010, c 9, s 50). British Columbia's current legislation differs from that of Alberta (and Saskatchewan) in two important respects. First, the legislation does not limit the amount that the BC Board can award or specify the time frame in which owners and occupants must bring an application for damages. Second, damage claims may concern lands to which the operator has an entitlement. See Roseland Creek Farms Ltd v Pengrowth Energy Trust, Mediation and Arbitration Board, Order No 1592-2 (15 April 2009), online: Surface Rights Board (British Columbia) $<$ http://www.surfacerights board.bc.ca/Documents/OilAndGasOrders/Order\%201592-2\%20Final.pdf $>$, where the BC Board considered awarding damages for damage caused by an oil spill to lands leased by Pengrowth. The BC Board determined that Roseland's claim must fail, for although there was temporary damage to the leased land due to the oil spill, the damage was sufficiently mitigated and remediated (ibid at para 23). The award was based on the old section 16 of the $P N G A$ (now repealed), but the current version still allows claims in relation to lands acquired by the operator.

As discussed below, in Wrangler West Energy Corp v Kaup, SRB Decision 2010/0338 (4 May 2010), online: SRB (Alberta) <http://www.surfacerights.gov.ab.ca/downloads/documentloader.ashx?id= 
proceeds as follows. We start with an overview of the statutory changes to section 30 since 1972. We then consider the Board's jurisdiction to award damages in light of its own decisions. A majority of the decisions discussed here involve claims against oil and gas well operators. ${ }^{10}$ Finally, the article uses three recent Alberta court cases to highlight some of the similarities and differences between the statutory cause of action created by section 30 and common law causes of action.

\section{BACKGROUND}

From 1947 through to 1972, the Right of Entry Arbitration Act ${ }^{11}$ governed the arbitration of compensation for rights of entry in connection with mining, drilling, and pipeline operations. The Act did not provide the Board with the authority to award damages for additional losses not covered by right of entry compensation. Therefore, owners and occupants had to bring damage claims before the ordinary courts, relying on common law causes of action. Claims for less than $\$ 2,000$ could be brought before the District Court, leaving those over $\$ 2,000$ to be decided by the Supreme Court of Alberta. ${ }^{12}$

In 1972 the 1972 Act replaced the REAA and the Board gained the authority to resolve damage disputes. Section 38 of the 1972 Act read:

38. The Board may, with the consent of the persons concerned, hold a hearing and make an order with respect to a dispute between an operator who is a lessee under a surface lease and an owner or occupant as to the amount of compensation payable

(a) for damage arising out of the operations of the operator to the land of the owner or occupant that is not subject to the surface lease, or

(b) for loss of or damage to livestock or other personal property of the owner or occupant arising out of the operations of the operator, whether or not the land on which the loss or damage occurred is subject to the surface lease, or

(c) for time spent or expense incurred by an owner or occupant in recovering any of his livestock that have strayed due to the act or omission of the operator, whether or not the act or omission occurred on the land that is subject to the surface lease. ${ }^{13}$

10881> [Wrangler West], section 30 of Alberta's SRA does not allow claims for damage to lands acquired by the operator in part because the operator is required to reclaim those lands before the end of its entitlement. One advantage of British Columbia's scheme may be that it fills a possible gap in Alberta's legislation relating to pipeline rights of entry. As pointed out by Lars Olthafer in comments to the authors, it is not clear that later damage to pipeline rights of entry (e.g. arising upon a later re-entry to right-of-way lands for repairs, etc.) can be claimed under section 30 of the $S R A$ - the reason being that the damage is not "off-site" and the operator must eventually obtain a reclamation certificate with respect to that land. This is problematic if the operator is not required to reclaim the land until long into the future and the landowner's ability to the use the land in the meantime is impaired. The SRB decisions can all be accessed online from <http://www.surfacerights.gov.ab.ca/ordersdecisions/ default.aspx $>$. See supra note 3.

RSA 1970, c 322 [REAA], as re-enacted by 1972 Act, supra note 5.

District Courts Act, RSA 1970, c 111, s 25 [DCA], as re-enacted by Court of Queen's Bench Act, SA 1978 , c 51.

Supra note 5, s 38. 
There are a few important differences between section 38 of the 1972 Act and section 30 of the current $S R A$. First, section 38 required the parties to a dispute to consent to a hearing before the Board, whereas section 30 does not mention consent. ${ }^{14}$ Second, section 38 confined the Board's jurisdiction to disputes involving surface leases; there was no mention of right of entry orders. Third, section 38 did not place a dollar cap on the Board's jurisdiction, nor did it contain an internal limitation period. At the same time that section 38 was in effect, owners and occupants could bring damage claims of any size before the District Court. Just prior to introducing the 1972 Act, the province amended the $D C A$, lifting the $\$ 2,000$ cap on that court's jurisdiction to hear and adjudicate damage claims. ${ }^{15}$

Shortly thereafter the Land Surface Conservation and Reclamation Act ${ }^{16}$ amended section 38 to eliminate the consent requirement but also to allow the Board to hear and adjudicate disputes between the parties to a right of entry order. Owners and occupants were allowed to file claims in relation to any of their lands, not only those lands "not subject to the surface lease. ${ }^{.17}$ As well, the amendments required owners and occupants to file applications within 120 days of the last date on which the damage was alleged to have occurred, and claims could not exceed $\$ 1,000 .{ }^{18}$ Finally, the amendments barred the Board from awarding damages for losses already covered by right of entry compensation orders.

Section 38 was amended again in 1976 to allow owners and occupants to claim up to $\$ 2,000 .{ }^{19}$ Two years after this amendment, Alberta's newly created Provincial Court was authorized to hear damage claims worth up to $\$ 1,000 .^{20}$ This meant that owners and occupants could bring damage claims under $\$ 1,000$ before two forums: the Board or the Provincial Court. Claims for over $\$ 1,000$ but less than $\$ 2,000$ could go before the Board or the Court of Queen's Bench. Claims for more than $\$ 2,000$ had to go to the Court of Queen's Bench. ${ }^{21}$ Of course, a damages claim before a court would have to be based upon a common law cause of action rather than the statute.

A new Surface Rights Act ${ }^{22}$ was adopted in 1983. The new 1983 Act reflected some of the recommendations of the Alberta Legislative Assembly Select Committee on Surface Rights (Select Committee), established in 1980 to carry out a total review of policies and legislation relating to surface rights in the province. ${ }^{23}$ The Select Committee recommended giving owners and occupants more time to file applications (two years from the time that the event took place) and allowing the Board to hear claims for up to $\$ 25,000 .{ }^{24}$ The first of these

There would be little incentive for the operator to consent given the strict nature of the liability created by the statute; see discussion below. Consent would likely make the section a dead letter.

An Act to Amend the District Courts Act, SA 1971, c 28, s 4.

SA 1973, c 34, s 65(c) [LSCRA], as re-enacted by Environmental Protection and Enhancement Act, SA 1992, c. E-13.3.

Section 38(a) was amended to read: "for damage caused by or arising out of the operations of the operator to any land of the owner or occupant." LSCRA, ibid.

Recalling the amendment referred to in supra note 15, owners/occupants seeking more than $\$ 1,000$ could bring their claims before a District Court, or to the District Court in 1975 when the two merged. Surface Rights Amendment Act, 1976, SA 1976, c 85, s10.

Provincial Court Act, 1978, SA 1978, c 70, s 36(1)(a)(ii).

The District Court of Alberta merged with the Trial Division of the Supreme Court of Alberta to form the Court of Queen's Bench under the Court of Queen's Bench Act, SA 1978, c 51.

Surface Rights Act, SA 1983, c S-27.1 [1983 Act].

Legislative Assembly of Alberta, Select Committee to Review Surface Rights, "Report of the Select Committee to Review Surface Rights" (November 1981) at 5.

Ibid at 23 . 
recommendations was adopted in the 1983 Act; however, the dollar cap on the Board's damages jurisdiction was raised only to $\$ 5,000 .^{25}$

The Board's damages jurisdiction has been amended three times since 1983. First, in 1987, the legislation was rewritten to clarify that damage must have occurred outside the area granted to the operator. ${ }^{26}$ Second, in 2001, the Board was permitted to hear claims for up to $\$ 25,000 .{ }^{27}$ Hansard debates from the time of this amendment suggest that legislators valued the Board's ability to resolve damage disputes. The Minister of Sustainable Resource Development described the Board's ability to deal with damage claims as "a quicker and more efficient channel for dealing with compensation than the court system" and added that increasing the dollar cap would "reduce the time spent or court expenses of an owner or occupant in recovering damages and allow an owner or occupant to receive full value for damages." 28 In 2002 the province amended the Provincial Court Civil Division Regulation to enable the Provincial Court to deal with damage claims worth up to $\$ 25,000 .{ }^{29}$ This means that owners and occupants now have two options with respect to damage claims for $\$ 25,000$ or less. They can apply for a hearing before the Board or they can appear in Provincial Court. Claims exceeding $\$ 25,000$ must be heard before the Court of Queen's Bench of Alberta. A claim in either court would have to be formulated within a common law cause of action it could not be based on section 30 .

The most recent legislative change to section 30 took place in 2009 when the word "hear" was removed from the section and "hearing" was replaced with "proceedings." ${ }^{30}$ This was a product of broader procedural amendments to the Act, intended to improve the efficiency of the Board. ${ }^{31}$ Among other things, the 2009 amendments authorized the Board to design and implement alternative dispute resolution processes, adopt as its decision the settlements reached by the parties in alternative dispute resolution processes, and make decisions on the basis of written submissions alone. ${ }^{32}$

In sum, the substance of the Board's damages jurisdiction has not changed significantly since 1973, aside from the 1987 amendment to clarify that claims must be based on damage to land outside the area granted to the operator. Amendments throughout the years have altered the amount of time that owners and occupants have to file claims, as well as the

Supra note 22, s 33. Alberta, Legislative Assembly, Hansard, 20th Leg, 1st Sess (31 May 1983) (Hon LeRoy Fjordbotten). The Hansard record provides some insight into why the Select Committee's recommendation to raise the dollar cap to $\$ 25,000$ was not accepted. Upon introducing the legislation for its second reading, the bill's proponent commented that $\$ 5,000$ was "really more in keeping with the realities of today" (ibid at 1254). After being questioned directly about why $\$ 5,000$ was chosen as the dollar limit, he stated: "There's no magic to that number, either. It was one that we felt was reasonable and in the realm of an administrative tribunal. It fit in there quite well. Also, it's two and a half times what the small claims court is. So that was just a number we arrived at that was reasonable considering the circumstances" (ibid at 1267).

Agriculture Statutes Amendment Act, 1987, SA 1987, c 2, s 8(7).

Surface Rights Amendment Act, 2001, SA 2001, c 12, s 2(c).

Alberta, Legislative Assembly, Hansard, 25th Leg, 1st Sess (24 April 2001) at 135-36 (Hon Mike Cardinal).

Provincial Court Civil Division Amendment Regulation, Alta Reg 215/2002, s 2. Prior to this, the Provincial Court could hear damages claims worth up to $\$ 7,500$. Provincial Court Civil Division Amendment Regulation, Alta Reg 179/97, s 2.

$30 \quad$ Surface Rights Amendment Act, 2009, SA 2009, c 31, s 14.

31 Alberta, Legislative Assembly, Hansard, 27th Leg, 2nd Sess, Issue 14 (12 March 2009) at 383 (Hon Kenneth R Kowalski).

SRA, supra note 1 , ss 8(2)(e), 8(3.2), 8(3.1). 
amount of money that the Board can award. Generally speaking, the upper limit of the Board's damages jurisdiction has been about the same as that of the province's lowest court. This is apparent now as both the Board and the Provincial Court have the jurisdiction to deal with damage claims for amounts up to $\$ 25,000$.

\section{THE BOARD's JURISPRUDENCE}

The following three sections examine the Board's damages jurisdiction in light of the Board's own decisions respecting section 30 claims. We focus on Board decisions because, while orders under section 30 can be appealed to the Court of Queen's Bench on the same basis as compensation orders, it seems that such appeals are rare. ${ }^{33}$ Thus, the courts have had few opportunities to interpret the section. ${ }^{34}$ Perhaps the most significant judicial comment on section 30 is in Jenkins v Alberta (Surface Rights Board). ${ }^{35}$ In Jenkins, an arbitration clause was included in the terms of a right-of-way agreement between the owner and operator. The owner filed a claim with the Board under section 33 (now section 30), alleging crop loss and other damage to their land caused by the operator's pipeline construction. The Board initially refused to hear the owner's claim on the basis that the damages sought were of the type normally granted in compensation hearings under section 25 of the SRA. Then, upon reconsideration, the Board declined jurisdiction on the basis of the arbitration clause. The owner applied for judicial review of the Board's decision and for an order requiring the Board to hear and decide the claim. The Court rejected the owner's application and concluded that the wording of section 33(1) was permissive such that the Board was under no obligation to hear and consider the matter. ${ }^{36}$

Two difficulties arise from relying solely on the Board's own decisions to analyze its jurisdiction under section 30. First, the Board is not always consistent in interpreting its jurisdiction under this section of the statute. For example, the Board has ruled in opposite ways on whether it has the jurisdiction to award damages for the act of trespass, aside from any actual damage to land. This example is described in more detail below. Second, the Board decisions sometimes fail to analyze and apply section 30 in a clear and methodical way, identifying, for example, that section 30 deals with claims involving three types of loss or damage: damage to land, loss or damage to livestock or other personal property, and time spent and expense incurred in recovering livestock. When awarding damages, the Board sometimes fails to refer to a specific head under section 30(1). In other cases, the Board

Ibid, s 30(4). Section 26(6) of the $S R A$ provides that "[a]n appeal to the Court shall be in the form of a new hearing," but in practice the courts do give some weight and deference to Board decisions: see Enbridge Pipelines (Athabasca) v Karpetz, 2010 ABCA 185, 490 AR 166 [Karpetz]; Imperial Oil Resources Ltd v 826167 Alberta Inc, 2007 ABCA 131, 404 AR 212 [Imperial Oil]; Whitehouse v Sun Oil Co (1982), 40 AR 380 (CA) [Whitehouse]. There is no reason for thinking that the situation has changed post-Dunsmuir (Dunsmuir v New Brunswick, 2008 SCC 9, [2008] 1 SCR 190) and the Karpetz case is authority for thinking that the standard of review for Board decisions will generally be reasonableness rather than correctness.

Court decisions that mention section 30 in passing or in relation to other matters, such as right of entry orders, seem easier to find. See e.g. Cymbalukv Alberta (Surface Rights Board), 2009 ABQB 263, 471 AR 166. (1996), 194 AR 214 (QB) [Jenkins]. Ibid at para 14. 
clearly specifies the heads of damages under which it is proceeding. Inevitably, this article relies more heavily on the group of more carefully reasoned decisions. ${ }^{37}$

The following analysis starts with a look at section 30(3), which serves a gatekeeper function with respect to the Board's damages jurisdiction. Next, we examine each heading under section 30(1). This is followed by a brief look at the Board's approach to claims for acts of trespass. Finally, we consider the Board's approach to proof of damage and proof of causation. Appendix A of the article provides a summary of the Board's section 30 decisions over the last ten years and offers some statistical summaries. The data in the Appendix shows that the Board has been deciding less than ten section 30 cases per year (a high of seven and a low of five) for a total of 61 cases over the ten-year period.

\section{A. Section 30(3)}

The section reads: "This section does not apply to a claim for compensation the amount of which may be determined by the Board under section 25.",38

Section 30(3) limits the Board's damages jurisdiction by preventing the Board from considering, in the context of a section 30 claim, a claim for loss or damage that will be or has already been compensated under section 25 . Section 25(1), the most intensely scrutinized section of the $S R A$, lists factors that the Board may consider in determining compensation for a right of entry order. In other words, section 25(1) lists types of loss and damage that the Board cannot compensate under section $30 .^{39}$ This includes the losses that an owner or occupant will sustain through not being able to use lands granted to the operator and the adverse effect of the granted area on the remaining lands of the owner or occupant. ${ }^{40}$

Section 25(5) includes additional factors that the Board may consider in determining right of entry compensation. Importantly, the section appears to focus on the same types of loss and damage as section 30(1), such as damage to land not granted to the operator, loss or damage to livestock or other personal property, and time spent and expenses incurred in

The Board has a statutory duty to provide reasons for its decisions. See Administrative Procedures and Jurisdiction Act, RSA 2000, c A-3, s 7 [APAJA] and Authorities Designation Regulation, Alta Reg 64/2003, s 1(b). The cases applying this section to the Board include Whitehouse, supra note 33; Pennzoil Petroleums Ltd v Jorsvick (1986), 78 AR 155 (QB) (reasons were inadequate because the Board failed to explain why it increased an annual compensation award, so the Board's decision was quashed); Dome Petroleum Ltd v Grekul (1983), 49 AR 256 at para 23 (QB), where Justice Miller noted that the Board can comply with the $A P A J A$ "if it clearly sets out the terms of reference under which it is making the awards, the general principles it will be applying, makes the necessary findings of fact where there is conflicting evidence and breaks the award down under generally accepted heads of damages. In my view, it is not necessary for the board to provide a detailed listing of the actual calculations it has used to come to their conclusions." See also Central Western Railway Corp v Alberta (Surface Rights Board) (1987), 56 Alta LR (2d) 115 at 134 (QB), where the right of entry order was quashed because the Board did "not disclose reasons for granting the right of entry" order or "for refusing to consider the jurisdictional question raised" by one party.

SRA, supra note 1, s 30(3).

See supra note 4.

SRA, supra note 1, ss 25(1)(c)-(d). While the SRB has a wide discretion in setting compensation, its own practice indicates that reference to loss of use and adverse effect are the foundations upon which compensation is determined. See Imperial Oil, supra note 33. 
recovering livestock. ${ }^{41}$ Unfortunately, Board and court decisions are virtually silent on the interplay between the two sections. ${ }^{42}$ Moreover, section 25(5) seems to factor seldom, if ever, into Board calculations of compensation orders. This is perhaps surprising given that right of entry orders will typically be exercised soon after they are granted and before the compensation hearing. In such a case, therefore, one would expect any off-site damage to be taken into account under section 25(5) rather than as part of a subsequent section 30 application. $^{43}$

Three Board decisions illustrate the effect of section 30(3) on the Board's damages jurisdiction. First, in Penn West Petroleum Ltd $v$ Dingwall, ${ }^{44}$ an operator travelled off its right-of-way and damaged some of the claimant's land. The operator subsequently (and prior to the section 30 hearing) received right of entry orders that allowed it to construct a new road where the damage occurred. The claimant filed a section 30 application, seeking compensation for the losses that it sustained as a result of the operator's trespass and compensation for losses that it would incur as a result of the right of entry orders. The Board awarded the claimant $\$ 600$ for the operator's trespass (under the heading "Trespass and Loss of Use") but refused to deal with the second part of the claim, stating that it "would be dealt with in the compensation hearing on the Right of Entry Orders." 45 This is clearly an unusual case which required the Board to carefully delineate the matters that could be dealt with under section 30 (based on the existing right of way) and the matters that were more closely related to future activities based on the new right of entry orders.

In Penn West Petroleum Ltd $v$ Froland, ${ }^{46}$ the claimant and operator were parties to a surface lease. The claimant alleged that it could not farm a portion of its remaining land because of the way in which the operator fenced off its well site and a portion of the access road. In addition to a claim for crop loss, which the Board granted, the claimant requested $\$ 1,000$ for their time spent meeting with the operator. The Board denied this aspect of the claim, stating that " $[\mathrm{t}]$ his is clearly a matter to be dealt with at the time of taking or under some circumstances in a surface lease review."

41 The main difference between sections 30(1) and 25(5) appears in section 25(5)(a): “for damage caused by or arising out of the operations of the operator to any land of the owner or occupant other than the area granted to the operator, if those operations were incidental to the operations of that operator on the area granted to the operator under the right of entry order," SRA, supra note 1, s 25(5)(a) [emphasis added]. There is also a timing difference. If section 25(5) damages have already occurred at the time of the section 25 hearing the Board will presumably proceed under this section. Where the damages occur after such an award has been made, an owner will presumably proceed under section 30 . 42 For judicial interpretation of section 25(5), see Voermans $v$ Alberta (Surface Rights Board) (1988), 87
AR $58(\mathrm{QB})$. The case centered on the right of entry compensation to be paid to an owner by the operator with a permit to construct and licence to operate a power line transmission on the owner's land. The owner ran a crop-dusting business. The power line passed over lands owned by the owner's neighbour in addition to his own. The existence of the power line on the neighbour's land interfered with the owner's use of an airstrip located on his own land. The owner contended, among other things, that he should be compensated under section 25(5) for the loss and damage suffered to his crop-dusting business "by reason of the operator's power lines above the air space of the adjacent landowner" (ibid at para 12). The Court reviewed the section and concluded that it does not permit consideration of acts "committed by the operator on lands not owned or occupied by a party to the Right of Entry Order" (at para 23). Olthafer drew this timing issue to our attention.

SRB Decision 2003/0057 (15 July 2003) [Dingwall].

Ibid at 3 .

SRB Decision 2007/0039 (6 March 2007) [Froland]. Ibid at 4. 
Finally, in Nexen Inc v Farm Air Properties, ${ }^{48}$ Farm Air applied under section 27 for a review of the rate of compensation paid to it by Nexen. Farm Air argued that Nexen's site had adversely affected its ability to build a subdivision on its remaining lands and that the revised rate of compensation should reflect this loss. In particular, Farm Air argued that hydrocarbon contamination from Nexen's site (and the associated remediation work) delayed work on the subdivision. The delay increased development costs and reduced the overall profitability of the venture.

For its part, Nexen argued that Farm Air should have brought its claim under section 30 of the SRA rather than section 27. The reason, according to Nexen, is that section 27 authorizes the Board to set a revised rate of compensation that takes into account "recurring or continuing losses," and the hydrocarbon contamination that occurred in this case was a one-time event. ${ }^{49}$

The Board rejected Nexen's argument that Farm Air's claim should have come under section 30. According to the Board, the losses complained of by Farm Air could be characterized as "adverse effects" under section 25(1)(d) of the $S R A$, and thus section 30(3) would prohibit the Board from considering them under section 30. The Board stated:

The Board has determined that "adverse effect" as that term is used in Section 25 is broad enough to include the consequences of operations on the area granted. Section 27 provides for the review of the rate of compensation as opposed to Section 30 which is intended to provide a "one time" determination of compensation for isolated events resulting [in] compensation of less than $\$ 25,000.00 .^{50}$

The Board went on to find that the claims advanced by Farm Air fell within the scope of section 27 in that they could be compensated through a revised rate of compensation even though they stemmed from a one-time event. ${ }^{51}$ This is interesting because many section 27 Board decisions use the language: "A rate of compensation must logically be presumed to compensate for those losses or damages which are of a recurring or continuing nature during the term of the lease. $" 52$

Thus, Dingwall, Froland, and Farm Air show that section 30(3) limits the damages jurisdiction of the Board to loss or damage that cannot be compensated through right of entry

SRB Decision 2008/0182 (10 July 2008) [Farm Air].

Ibid at 6.

Ibid at 11 .

Ibid at 12 .

See e.g. Petro Canada v Wild Dog Enterprises Ltd, SRB Decision 2009/0257 (14 July 2009) at 5; Arc Resources Ltd v Styner, SRB Decision 2009/0088 (26 March 2009) at 7; Standard Energy Inc v 1099342 Alberta Inc, SRB Decision 2009/0076 (19 March 2009) at 7. 
compensation. ${ }^{53}$ We now turn to section 30(1) and the types of loss and damage that owners and occupants can recover under section 30 .

\title{
B. SeCtion 30(1)(A)
}

In order for an owner or an occupant to establish a claim under this head it must show: (1) that damage was caused by or arose out of the operations of an operator, (2) that the damage occurred on its land, and (3) that the operator has no entitlement to land on which the damage occurred. The third requirement makes sense for two reasons. First, in determining compensation in relation to right of entry orders, section 25(1)(e) permits the Board to consider "damage to the land in the area granted to the operator that might be caused by the operations of the operator." 54 There would be a risk of overlap and double compensation if section 30 authorized the Board to award damages in relation to lands granted to the operator. Second, operators are already under a duty to reclaim the lands granted to them. ${ }^{55}$ In Wrangler West, the Board noted that part of a section 30 claim concerned damage to land within the operator's access road right-of-way and stated:

\begin{abstract}
The Act contemplates that some damage to the land will occur during the construction/operation of pipelines and access roads within the rights-of-ways. In addition, the Operator is required to obtain a reclamation certificate when they turn the area granted by the right-of-ways back to the landowner. In order to obtain the reclamation certificate, the Operator will have to address any damage caused by such issues as intermixing of clay and sand with topsoil, topsoil contamination, etc. ${ }^{56}$
\end{abstract}

Once it is established that an operator has no entitlement to the damaged land, owners and occupants can recover basic pecuniary losses under section 30(1)(a), such as the cost of repairing the land. For example, in Signalta Resources Ltd $v$ Blum $^{57}$ the operator drove off their right of way and caused rutting and erosion on the claimant's farm land. The Board awarded $\$ 2,345$ to the claimant to cover the repair costs, an amount "based on custom rates supplied by Alberta Agriculture." 58

53 Two additional decisions highlight the fact that the Board's damages jurisdiction does not permit awards for losses that have been or will be compensated under section 25. See Equatorial Energy Inc v Day, SRB Decision 2001/0128 (25 May 2001). The claimant alleged that during the preparation of a well site in 1953, the operator pushed soil off its site, left the soil piled on the claimant's remaining land, and trees grew up through the soil over time. After hearing evidence from both parties, the Board determined that the nuisance trees were located on lands that were recently granted to the operator under a right-of-way. The Board stated (ibid at 2): "[T]he Board will not award any monies for damages as the damaged land is part of the Right of Entry Order and will be covered by the compensation for the Right of Entry of 2.60 acres." See also Baytex Energy Ltd v Heidinger, SRB Decision 2004/0082 (25 November 2004). The claimant sought damages for time spent monitoring and closing a gate which the operator was allegedly opening. The Board rejected this portion of the claim and stated (ibid at 10):

Claims for closing gates are not applicable under Section 30 of the Surface Rights Act. The Board finds claims of this nature to be covered by the Operator's annual payment under the heading of adverse effect. In this instance the Operator is currently paying the Heidingers $\$ 15,050.00$ per year for adverse effect. Adverse effect is intended to provide compensation for a variety of ongoing matters including meetings with the Operator, working around well sites, monitoring gates and

fences, nuisance, and inconvenience. Therefore, this portion of the claim is denied.

SRA, supra note $1, \mathrm{~s} 25(1)(\mathrm{e})$.

Environmental Protection and Enhancement Act, RSA 2000, c E-12, s 137 (imposes a duty to reclaim). Wrangler West, supra note 9 at 13.

SRB Decision 2004/0081 (17 November 2004).

Ibid at 3. 
Owners and occupants can also recover consequential losses, such as loss of profit, under section 30(1)(a). In Altalink Management Ltd v Sloan ${ }^{59}$ the Board considered whether the operator's act of felling 150 trees near the transmission line right-of-way caused damage to the plaintiff's land. To answer this question, the Board considered definitions of "damage" in Black's Law Dictionary and the Oxford English Dictionary. Fusing the definitions from these two sources, the Board held: "Mr. Sloan has a legitimate argument that his property has suffered a deterioration, or diminution, or [has] been [lessened] in value as a result of the felling of the trees in question." 60

The claimant in Sloan proposed two methods for calculating damages. The first was based on the retail value of a cord of firewood. The Board rejected this method, stating: "There had been no routine harvesting" of firewood on the claimant's land and that the retail value of firewood includes inputs such as the costs of "cutting, splitting, bundling and transporting." The claimant based his second assessment on the cost of replacing the felled trees $(\$ 100$ per tree). The Board rejected this method too, on the basis that moving mature trees into the area was infeasible. ${ }^{62}$

In the end, the Board in Sloan accepted the operator's method for calculating damages, which was based on the value of "merchantable timber" ranging from $\$ 2.50$ to $\$ 4.00$ per tonne. Twenty-five tonnes of merchantable timber had been felled, and thus the claimant was entitled to an award ranging from $\$ 62.50$ to $\$ 100.00$. The Board awarded $\$ 100$ and stated:

Whether or not the Landowner had any intention to market the trees at the time of their felling is irrelevant.

The trees were felled, diminishing their value, and the opportunity for the Landowner to realize their worth

as 'merchantable timber' ceased. The Board finds that it is a reasonable expectation that the Operator compensate the Landowner for that loss. ${ }^{63}$

The claimant in Wrangler West Energy Corp v Christen ${ }^{64}$ also recovered lost profits after the operator accidentally sprayed chemicals on some of its canola crop. The Board determined that damages were available for this loss under section 30(1)(a). Damages were calculated by multiplying the size of the area affected by the chemicals ( 4.514 acres) by half of the amount of canola normally yielded by the area (27.5 bushels) and by the price the claimant received for its canola under a contract $(\$ 16)$ for a total of $\$ 1,986.16$ (rounded to $\$ 1,990) .{ }^{65}$

In addition to loss of profits, owners and occupants can recover another type of consequential loss under section 30(1)(a) - loss of use. For example, in Arc Resources Ltd $v$ Dugan, ${ }^{66}$ the operator removed a portion of the claimant's fence while constructing its well site. About nine months passed before the operator repaired the fence. Throughout the ninemonth period, the claimant purchased food for its cattle instead of allowing them to graze.

SRB Decision 2009/0280 (4 August 2009) [Sloan].

Ibid at 5 [emphasis in original].

Ibid.

Ibid at 3, 5 .

Ibid at 6 .

SRB Decision 2010/0247 (25 March 2010) [Christen].

Ibid at 6.

SRB Decision 2010/0243 (24 March 2010) [Dugan]. 
The claimant then brought a claim under section 30, seeking to recover the money spent on alternate feed. The Board found that the operator had damaged the claimant's land, and therefore the claimant was entitled to damages for its loss of use. To calculate damages, the Board considered evidence of pasture rental rates in the area. The evidence indicated that for a herd of cattle such as the claimant's, pasture rental rates would range from $\$ 3,700$ to $\$ 7,920$ per season. The Board commented that "the higher end of the range was appropriate in this matter," but fixed the damages at $\$ 5,000$ because the claimant had not lost the use of its pasture land for an entire season. ${ }^{67}$

The Board has also awarded damages under section 30(1)(a) where a claimant incurred a loss of time but the actual damage to land was minimal. For example, in Greenfield Resources Ltd $v$ Gunderson ${ }^{68}$ a rig worker camped and littered on the claimant's remaining land. The claimant sought $\$ 3,000$ under section 30 for the trespass and littering. The Board concluded that it lacked "jurisdiction to deal with the actual act of trespass." "'However, the litter "constitut[ed] damage to adjoining property as defined under section 30(1)(a) of the Act." ${ }^{, 70}$ In turn, the claimant received $\$ 1,000$ "in compensation for the time and effort required to clean up the adjoining land." 71

Gunderson raises a question about the threshold for a damages claim under section $30(1)$ (a). The case suggests that, in some instances at least, very minor damage to land can attract an award under section 30. In other instances, the Board has rejected claims for very minor damage to land. For example, in Baytex Energy Ltd $v$ Dandell, ${ }^{72}$ the Board relied on its own site inspection to determine whether the operator trespassed on and damaged the claimant's remaining land. The inspection revealed some rutting (caused by the operator's snowplough), but the Board denied the claim based on the minor nature of the damage. ${ }^{73}$

\section{SECTION 30(1)(B)}

To establish a claim under this head, the owner or occupant must show: (1) loss or damage to its livestock or other personal property; and (2) that the loss or damage arose from the operations of the operator. Claimants under this head do not need to show that the loss or damage occurred on their remaining land.

Owners and occupants can use section 30(1)(b) to recover pecuniary losses associated with livestock, such as the cost of replacing or treating injured livestock. For instance, in Bearspaw Petroleum Ltd v Brenchley ${ }^{74}$ several calves fell into a hole dug by the operator. The claimant sought damages to cover the costs of replacing the lost calves. In addition, the claimant argued that the fertility of some of its cows had been negatively affected by the loss of the calves. The Board found in favour of the claimant and calculated damages based on

Ibid at 5 .

SRB Decision 2008/0062 (6 March 2008) [Gunderson].

Ibid at 7.

Ibid.

Ibid.

SRB Decision 2006/0118 (31 July 2006) [Dandell].

Ibid at 3.

SRB Decision 2009/0202 (2 June 2009) [Brenchley]. 
the cost of replacing the lost calves $(\$ 2,500$ for purebreds and approximately $\$ 500$ to $\$ 600$ for commercial calves) and the costs of transporting and replacing the cows.

Owners and occupants can also recover losses stemming from damage to "other personal property" under section 30(1)(b). ${ }^{75}$ In Vintage Petroleum Canada Inc v Kucher ${ }^{76}$ the operator's survey crew left unmarked holes and a stake on the claimant's remaining land, which later caused damage to the claimant's farm equipment. The claimant sought damages for replacement parts for his equipment. The Board awarded damages to cover the costs of repairing (not replacing) the damaged parts because the claimant's farm equipment was old, and the Board was concerned that the claimant "placed his machinery in harm's way by operating in the vicinity of the holes he had struck previously."77 The Board stated:

Surely, Mr. Kucher has to assume some responsibility to mitigate his losses. For example, he could have marked the holes. This would have enabled the Operator to find and repair the obstacles and would have also enabled Mr. Kucher to avoid the subsequent risk to his machinery in the future. ${ }^{78}$

Finally, owners and occupants sometimes recover losses caused by damage to crops or pasture land under section 30(1)(b) (as opposed to under section 30(1)(a)). Two cases help to illustrate this point. First, in Kyjo Resources Ltd $v$ Tees ${ }^{79}$ the operator used frozen earth to backfill its pipeline construction. The land above the pipeline was then less productive than it had been in previous years and the claimant pursued damages for crop loss. In finding for the claimant, the Board stated that crop loss is a loss of personal property and awarded damages under section 30(1)(b). ${ }^{80}$ Second, in Paramount Energy Operating Corp v Mucha ${ }^{81}$ the operator left the well site unfenced and reworked the pipeline right-of-way in such a way that the claimant could not pasture his cattle in the area. The claimant fed his cattle baled hay and brought a claim under section 30 for the costs of the baled hay. The Board found in favour of the claimant and stated: "Baled hay, which is deemed to be personal property by the Board, had to be used to feed cow/calf pairs in the fall of 2004, 2005, and 2006 resulting in a loss to the Lessor as a result of the operations of the Operator per sub-section 30(1)(b)." ${ }^{, 82}$

These two cases should be compared with Christen and Dugan. In Christen, the Board awarded damages for crop loss under section 30(1)(a) rather than 30(1)(b). ${ }^{83}$ Dugan involved facts similar to those in Mucha - that is, the operator's actions prevented the claimant from pasturing its cattle. However, in Dugan, the Board awarded damages under section $30(1)(a){ }^{84}$

SRA, supra note $1, \mathrm{~s} 30(1)(\mathrm{b})$.

SRB Decision 2003/0017 (20 March 2003) [Kucher].

Ibid at 5 .

Ibid.

SRB Decision 2002/0121 (19 September 2002).

Ibid at 4.

SRB Decision 2008/0165 (19 June 2008) [Mucha].

Ibid at 8.

Supra note 64 at 6 . In other cases involving crop loss, the Board does not say under which heading damages are awarded. See Apache Canada Ltd v Lee, SRB Decision 2005/0099 (7 September 2005), where the operator's well sprayed salt water on 20.5 acres of canola field; Nuvista Energy Ltd v Tomkins, SRB Decision 2005/0003 (7 January 2005), where the Board found that soil erosion originated in an area leased to the operator and spread to 12 acres of off-lease land. 


\section{SECTION 30(1)(C)}

This head of section 30 requires an owner or occupant to show: (1) time spent or expenses incurred recovering stray livestock, and (2) that the livestock strayed due to an act or omission of the operator. Two cases illustrate how damages are calculated under this heading with respect to lost time and expense. First, in Brenchley, several calves went missing. Eventually their bodies were found in a drilling hole. In addition to the costs of replacement livestock, the claimant sought damages for time spent searching for the calves (at a rate of $\$ 75$ per person, per hour). The operator proposed a rate of $\$ 30$ per person, per hour. In the end, the Board awarded the claimant $\$ 50$ per person, per hour, for a total of $\$ 1,875 .^{85}$ The Board gave no reason for this number, but it seems reasonable to think that the Board wanted to reconcile the positions of the parties and simply split the difference. Second, in Kucher, the operator damaged a fence and some of the claimant's cattle escaped. The claimant did not request a specific amount for time spent rounding up the cattle. The Board accepted the operator's proposal to pay $\$ 150$ and added an additional $\$ 75$ to cover the claimant's truck rental. ${ }^{86}$

The cases of Brenchley and Kucher demonstrate that damages are available under section $30(1)$ (c) for time spent retrieving livestock. In some cases, the Board has awarded damages under section 30(1)(c) for time spent in other ways. For example, in Gunderson the Board awarded $\$ 600$ under section 30(1)(c) for time spent watching cattle to ensure that there was no escape ${ }^{87}$ In $K u c h e r$, the claimant received a small award for time spent picking rocks. ${ }^{88}$ Interestingly, in Mucha, the Board stated very clearly that owners and occupants could not be compensated for time spent picking rocks under section 30. The Board stated: "Section 30 is explicitly and exclusively concerned with damages to land or to crops or to livestock or other personal property of the owner or occupant [see sections 30(1)(a), (b), (c)]." ${ }^{\prime 99}$ Finally, in Bonterra Energy Corp $v$ Miller ${ }^{90}$ the operator's pipeline ruptured near the claimant's home and the cleanup took several months. The Board awarded the claimant $\$ 2,500$ under the heading of "Nuisance and Inconvenience" for its "considerable time and energy in dealing with the Operator." "91 The Board explained: "This would include time spent in protecting her interests, gaining an understanding of how and when the spill would be remediated, and writing letters to the Operator outlining her losses and concerns." 92 The claimant also received $\$ 2,500$ under the heading of "General Disturbance" for the disruptions to her animal management routines and because the noise and odours associated with the rupture and cleanup "detract[ed] from the ordinary amenities of residential living." 93

\section{E. TRESPASS}

Occasionally, owners and occupants pursue damages under section 30 after operators enter their remaining lands without permission. In Gunderson, for example, a rig worker camped

Supra note 74 at 8 .

Supra note 76 at 6.

Supra note 68 at 8.

Supra note 76 at 6.

Supra note 81 at 8 .

SRB Decision 2004/0078 (5 November 2004).

Ibid at 6 .

Ibid.

Ibid. 
and littered outside of the operator's lease site, and the claimant pursued section 30 damages for the trespass. In response, the Board said it lacked "jurisdiction to deal with the actual act of trespass." 94

In Apache Canada Ltd $v$ Jahner, ${ }^{95}$ the Board took a different view of its jurisdiction to deal with actual acts of trespass. In Jahner, the operator drove a heavy truck over part of the claimant's hay field. The claimant did not seek damages for crop loss. Rather, the claim (for $\$ 6,000)$ related specifically to the trespass. ${ }^{96}$ The operator admitted entering onto the claimant's land and offered to pay $\$ 600$ as compensation. In coming to its decision, the Board first noted that under section 30 , it had no jurisdiction to deal with the claim since "section 30 is explicitly and exclusively concerned with damages to land or to crops or to livestock or other personal property of the owner or occupant [see section 30(1)(a), (b), (c)]." ${ }^{, 97}$ The Board then stated:

\begin{abstract}
Although a claim initiated under the section 30 application process eventually proved to be not appropriate, evidence brought by both parties at the Hearing clearly demonstrated that there had been an instance of unauthorized land use by an agent of the Operator. At the Hearing, Mr. Strynadka [the occupant] chose to focus on this point and he asked the Board for remedy. The Board, under section 38 of the Surface Rights Act, has the right and duty to make an award for a trespass if certain conditions are met, namely:
\end{abstract}

\title{
Unauthorized land use
}

38 Notwithstanding the Petty Trespass Act, a person who, in the exercise of a right of entry, enters on, uses or takes any of the surface of land in contravention of this Act

(a) is deemed to have committed a trespass, and

(b) is liable in damages or otherwise for the trespass to any person who is the owner or the occupant entitled to the possession of the surface of the land. ${ }^{98}$

The Board did not explain how section 38 provides it with jurisdiction to award damages for trespass, but went on to find that $\$ 600$ (the amount offered by the operator) was a "reasonable, although not specifically grounded, compensation for the uncontested fact of an off-lease vehicular travel and for any time spent by the Lessor and Occupant in meetings with the agents of the Operator." 99

Finally, in Wrangler West, the operator drove around a mud hole on its access road right of way and caused some minor damage to the claimant's remaining land. The Board referred to Jahner as another case involving minor damage to land and determined that the claimant in Wrangler West was also entitled to $\$ 600 .{ }^{100}$

Ibid. The better view is that section 38 makes it easier for an owner to prove trespass in the common law courts. It manifestly does not give a new jurisdiction to the Board.

Supra note 9 at 12 . 
Thus, in Jahner and Gunderson the Board reached different conclusions about its jurisdiction to award damages for actual acts of trespass. The more recent decision in Wrangler West suggests that the Board will continue to award damages for acts of trespass (that is, situations where the operator is on lands not covered by an entry order or private agreement), at least where the operator causes damage that results in a tangible loss to the owner.

\section{F. Proof of Damage and Causation}

A party advancing a claim under any head of section 30(1) must always show: (1) that loss or damage occurred, and (2) that the loss or damage was causally connected with the operator or operations of the operator. Board decisions rarely refer to the standard of proof that the Board requires with respect to damage and causation. The case of Kucher is an exception there the Board explicitly mentioned the balance of probabilities as the standard. In Kucher, the operator admitted to leaving holes and a stake on the claimant's land but disputed that these things damaged the claimant's farm equipment. In its decision, the Board determined that there was enough evidence to "consider on the balance of probability that the damage to the tire did indeed occur as a result of the Operator's action."101 In view of this statement in Kucher, it seems reasonable to think that the standard of proof that section 30 claimants must meet is the civil standard on a balance of probabilities. This is consistent with high authority. ${ }^{102}$ The remainder of this section discusses how section 30 claimants prove damage and causation.

In many section 30 claims the operator admits to causing damage but disagrees with the claimant about the extent of the damage or the amount of money that is owed. A claimant then has to show that their claim is reasonable, given the particular circumstances. For example, in Brenchley the operator agreed that the claimant was entitled to damages for calves that fell into a drilling hole. But the operator objected to paying damages for cows that the claimant sold (after concluding that their fertility was adversely affected by the loss of the calves) on the basis that the sale was a business decision on the claimant's part. In the end, the claimant convinced the Board that they had no choice but to sell the cows (that is, they were simply a strain on their resources) and received damages in respect of the money lost on their sale.

In cases where the operator denies causing damage, a credible third party witness is especially important to the claimant's case. In Canadian Natural Resources Ltd v Guelly, ${ }^{103}$ the claimant alleged that the operator blocked a culvert and caused flooding and erosion on his farmland. The claimant's evidence consisted of their own testimony (contradicted by that of the operator) and photographs that, by the claimant's own admission, did not show damage very clearly. ${ }^{104}$ The Board denied the claim, finding that the claimant failed to prove that any damage occurred. The Board pointed to the fact that the claimant did not engage a third party witness and stated: "In making a claim for damages it is absolutely incumbent 
upon the claimant to provide the Board with useful evidence and information. When this is lacking, the Board is left with no reasons upon which to justify an award for damages."105

With respect to causation, claimants must show that the operator or the operations were a "direct cause" of the loss or damage. In Talisman Energy Inc v Dayment, ${ }^{106}$ the claimant alleged that a release of hydrogen sulphide from the operator's well had adversely affected the fertility of his bulls. The operator agreed that hydrogen sulphide was released and that the claimant's bulls were nearby at the time but disputed having caused any problems in the herd. At the hearing, a veterinarian testified on behalf of the operator. The claimant was unable to support their allegations with expert opinion. The Board denied the claim and stated: "Mr. Dayment's presentation contained many suppositions and 'what ifs' with no clear evidence that $\mathrm{H}_{2} \mathrm{~S}$ was a direct cause of his bulls being affected, resulting in failure of the Breeding Soundness Exams."107

The case of Omers Energy Inc v Grykuliak ${ }^{108}$ further demonstrates that claimants must establish "direct cause" to succeed before the Board. The claimant in Grykuliak argued that it was forced to spray 460 acres of his farmland with herbicide because mayweed had spread from the operator's lease site. The operator's evidence showed that they had taken measures to control weeds on the lease site and that there were other sites near the claimant's farmland from which mayweed could have spread. The Board sided with the operator and stated: "the Board could find no direct evidence that the Operator had directly caused the alleged contamination, therefore the Board will dismiss the claim."109

The above quotation from Grykuliak suggests that claimants must provide direct evidence of causation in order to recover losses under section 30. But this is not always the case. The Board has awarded damages where the claimant was unable to provide direct evidence of causation. In Penn West Petroleum Ltd v Smith, ${ }^{110}$ the claimant alleged that two of his whitetail deer panicked and ran into a fence (fatally injuring themselves) after the operator's engine repeatedly backfired. The operator argued that there was no evidence to support this allegation - that is, no one saw the deer panic or run, and there were no autopsy results to indicate how the deer died. Nevertheless, the Board found in favour of the claimant.

In Baytex Energy Ltd $v$ Heidinger ${ }^{111}$ the operator began work on the pipeline without notifying the claimant and while some of the claimant's cattle were nearby. The claimant alleged that the construction work caused three cows to contract dust pneumonia. As in Smith, the claimant had no autopsy results showing the precise cause of the cattle deaths. Nevertheless, the Board awarded damages for the dead cows. The Board reasoned that construction "caused considerable dust," and since "there were no previous deaths" in the herd and none following the construction, the dust "probably caused the deaths.".112

\footnotetext{
$105 \quad$ Ibid at 6 .

106 SRB Decision 2006/0159 (10 November 2006) [Dayment].

$107 \quad$ Ibid at 8

108 SRB Decision 2006/0139 (3 October 2006) [Grykuliak].

$109 \quad$ Ibid at 4

110 SRB Decision 2008/0158 (12 June 2008) [Smith].

111 SRB Decision 2002/0248 (16 December 2002) [Heidinger].

$112 \quad$ Ibid at 4
} 


\section{G. The NATURE OF Liability Under Section 30}

Finally, it is important to emphasize that an owner need not prove fault or negligence in order to succeed under section 30. In other words, section 30 imposes strict liability on an operator. Two considerations support this proposition. The first is a plain language reading of the section. ${ }^{113}$ Sections 30(1)(a) and (b) simply refer to damage arising out of the "operations of the operator"; they do not add the words (or equivalent) "except where damage arises out of normal, everyday operations." 114 Section 30(1)(c) refers to an "act or omission of the operator"; there is no suggestion that the act or omission must be negligent or that the owner or occupant must prove negligence. ${ }^{115}$ Second, the Board decisions do not grapple with the issue of fault. For instance, in Smith, the Board did not inquire into whether the operator could have done anything to prevent its engine from backfiring or whether there were other measures that the operator might have taken to protect the claimant's livestock. One would expect the Board to discuss or address these types of questions, unless the operator is subject to strict liability. We conclude that the section establishes strict civil liability and perhaps more correctly, absolute liability. ${ }^{116}$

\section{Common Law Tort Causes of Action}

Common law tort causes of action are another way for an owner or occupant to recover losses caused by an operator on their land by right of a surface lease or right of entry order. Below, we summarize three recent Alberta cases involving plaintiff-landowners and defendant-operators: Jones v Mobil Canada Ltd, ${ }^{117}$ Ball v Imperial Oil Resources Ltd,${ }^{118}$ and Blatz v Impact Engery Inc. ${ }^{119} \mathrm{Next}$, we compare the obstacles to recovery faced by plaintiffs in tort actions with those faced by claimants under section 30 .

Jones involved actions in negligence and nuisance for losses arising from deaths and poor performance in the plaintiff's herd of purebred cattle. The plaintiff alleged that Mobil exposed his cattle to oil and gas contaminants by improperly fencing a well site and through the seepage of contaminants onto the plaintiff's land from a flare pit buried on its lease site in 1973 by Mobil's predecessor, Canadian Superior.

On the plaintiff's claim in negligence, Justice Romaine found that Mobil breached the duty of care owed to the plaintiff with respect to the fence around its well site. This was a duty to fence in a way that would effectively prevent the plaintiff's cattle from accessing oil and gas contaminants. ${ }^{120}$ This broad duty arose because the plaintiff had already complained

113 Elmer A Driedger, Construction of Statutes, 2d ed (Toronto: Butterworths, 1983) at 87 states "the words of an Act are to be read in their entire context and in their grammatical and ordinary sense harmoniously with the scheme of the Act, the object of the Act, and the intention of [the Legislature]."

SRA, supra note 1, ss 30(1)(a)-(b).

Ibid, s 30(1)(c).

Absolute liability may be a better description because there is no suggestion that an operator can avoid liability by showing that he or she took all possible measures to avoid causing harm to the owner. See $R v$ Sault Ste Marie (City of), [1978] 2 SCR 1299.

(1999), 248 AR 1 (QB) [Jones].

2008 ABQB 765, 21 Alta LR (5th) 169 [Ball].

2009 ABQB 506, 478 AR 1 [Blatz].

Supra note 117 at para 134. Justice Romaine cited Girletz v Bailey Selburn Oil \& Gas Ltd (1975), 65 DLR (3d) 533 (Alta SC (TD)), where the defendant operated oil wells on the plaintiff's land, adjacent to where the plaintiff raised dairy and beef cows. The plaintiff alleged that Bailey Selburn was liable in nuisance and negligence for the loss of 29 cows, plus other consequent damages. In considering the 
to Mobil about the fencing and because Mobil's employees knew that oil and gas could harm cattle. $^{121}$

To establish its claim in nuisance, the plaintiff had to prove that Mobil wrongfully interfered with the use of his property or allowed a noxious substance to escape onto its land, and that damage to the land had resulted. ${ }^{122}$ The plaintiff met this requirement by showing that contamination had spread to its soil and groundwater from the flare pit buried by Canadian Superior. ${ }^{123}$ Citing Lewis Klar in Carmel Holdings Ltd v Atkins, ${ }^{124}$ Justice Romaine explained that a defendant who creates the conditions that lead to nuisance may be found liable without negligence. ${ }^{125}$ Therefore, even though Mobil exercised reasonable diligence in cleaning up the flare pit, the company could still be held liable for any damage done to the plaintiff's land from the initial spread of contaminants. ${ }^{126}$

The plaintiff relied on the expert testimony of an agrologist to prove that it had sustained damage. The agrologist testified that the plaintiff's cull rate was high compared to the industry average (particularly in 1987 to 1989 when the plaintiff's cull rate was double the industry average), as was the plaintiff's rate of calf death. Justice Romaine concluded that the comparisons drawn by the agrologist established problems in plaintiff's herd of cattle. ${ }^{127}$

Finally, the plaintiff in Jones had to establish a causative link between the problems in their herd and Mobil's failure to erect adequate fencing and/or the spread of contaminants from the flare pit. Importantly, there was no real issue in Jones as to whether the herd was exposed to oil and gas contaminants from time to time. ${ }^{128}$ There was also direct evidence to show that the plaintiff's cattle ingested contaminants. The plaintiff testified to seeing this happen, and test results showed oil and gas contaminants in the bodies of dead cattle. Nevertheless, the issue of causation was complicated by the symptoms displayed by the plaintiff's cattle: loss of appetite, failure to thrive, and long-term reproductive problems. ${ }^{129}$ The experts who testified on behalf of Mobil pointed to a selenium deficiency in the cattle as a potential cause of these symptoms. Expert testimony for the plaintiff identified the ingestion of oil and contaminants as a more likely cause but did not rule out the possibility of others.

The plaintiff ultimately succeeded in proving causation. Justice Romaine relied on Snell $v$ Farrell $^{130}$ for the proposition that a plaintiff does not have to prove causation with scientific precision and on Athey $v$ Leonati ${ }^{131}$ for the proposition that a defendant is liable for the plaintiff's injury so long as the defendant materially contributed to the injury. Mobil was

plaintiff's claim in negligence, the Court found that the defendant fenced its oil wells in accordance with accepted industry practices; however, pools of oil formed outside of the fencing, within reach of the plaintiff's cattle. The defendant's employees admitted to knowing that cattle could be harmed by crude oil. This knowledge, the Court found, changed the defendant's duty from that of the industry standard to a duty to keep the cattle away from the crude oil.

Ibid.

Ibid at paras 121, 142.

Ibid at para 144.

(1977), 2 CCLT 227 (BCSC) at 230.

Supra note 117 at paras $147-48$.

Ibid at para 149.

Ibid at paras 155, 157.

Ibid at para 166 .

Ibid at para 167.

[1990] 2 SCR 311.

[1996] 3 SCR 458. 
found to have materially contributed to the poor performance of the plaintiff's cattle because the cattle's health improved once they were no longer exposed to oil and gas contaminants. ${ }^{132}$ The plaintiff received $\$ 137,700$ for loss of cattle, $\$ 9,100$ for costs associated with selling off injured cattle, and $\$ 30,000$ in general damages for the extra time spent culling injured cattle. $^{133}$

Ball also involved claims in negligence and nuisance for losses stemming from health problems in the plaintiff's herd of cattle. ${ }^{134}$ The plaintiff alleged that in July 2002, Imperial exposed half of its herd to oil and gas contaminants while fixing a pipeline leak specifically, by taking soil from beneath the pipeline leak and placing it on a tarp where the plaintiff's cattle could access it, and pouring barrels of water pumped from the excavation site onto the plaintiff's land.

With respect to the plaintiff's claim in negligence, Justice McDonald found that Imperial owed the plaintiff a duty of care to conduct its operations, including pipeline repairs, in "a manner that would reduce the risk of harm to the Plaintiff and her property (including livestock) as much as reasonably possible." 135 Imperial breached this duty by failing to give the plaintiff adequate notice before starting the repair work and through the actions it took while repairing the pipeline (such as by pouring contaminated water on the ground and leaving contaminated soil out on a tarp). ${ }^{136}$

The trial judge cited Jones for the proposition that in order to succeed in nuisance the plaintiff must establish that the defendant allowed a noxious substance to escape onto its land and that the escape resulted in property damage. ${ }^{137}$ The plaintiff met these conditions simply by showing that hydrocarbons escaped from Imperial's pipeline and entered into the soil and water that filled the excavation. ${ }^{138}$

As in Jones, the issue of causation was difficult for the plaintiff in Ball to establish. One reason was that no one saw the plaintiff's cattle ingest oil and gas contaminants. Second, expert testimony on behalf of the defendant pointed to other issues as more likely causes of the poor health in the plaintiff's herd, including nutritional issues, husbandry issues, and general environmental conditions. But despite these difficulties, the trial judge determined that Imperial's actions had materially contributed to the poor health of the cattle. ${ }^{139}$ The plaintiff received $\$ 41,111.92$ for basic losses, $\$ 4,548.20$ for veterinary expenses, and $\$ 20,000.00$ in general damages for the inconvenience of dealing with sick livestock. ${ }^{140}$

The Court of Appeal upheld the trial judge's decision in Ball by a 2:1 majority. ${ }^{141}$ Imperial advanced four grounds of appeal. The first three grounds concerned the trial judge's

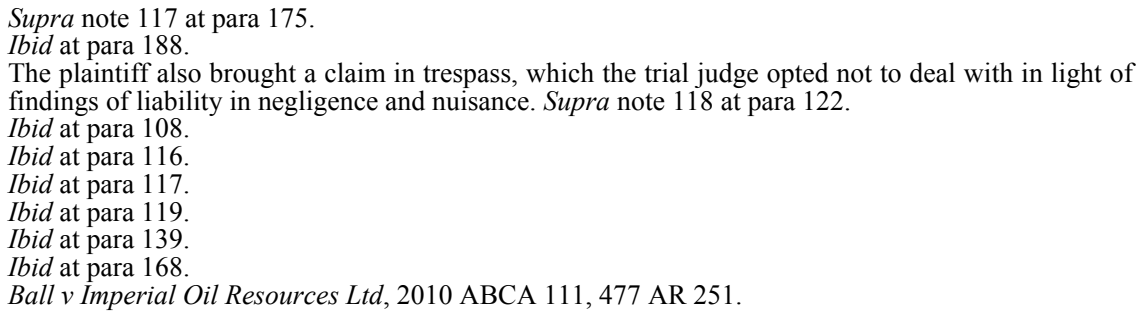


treatment of evidence respecting: (1) whether the plaintiff's cattle ingested contaminated soil, (2) whether the plaintiff's cattle were exposed to toxic levels of hydrocarbons, and (3) whether hydrocarbon exposure can produce the symptoms reported by the plaintiff. Imperial's fourth ground of appeal held that the trial judge applied the wrong test for causation.

Regarding the first three grounds of appeal, the majority, Justices Conrad and O'Brien, found that the trial judge failed to set out the evidence from which he inferred causation. As well, the trial judge failed to state reasons for rejecting or assigning little weight to the defendant's evidence. But these omissions were not fatal. For all three grounds of appeal, the majority determined that the evidence before the trial judge justified the inferences that were drawn. For instance, although there was no direct evidence before the trial judge on the matter, the majority considered that it was possible to infer (implicitly) that the plaintiff's cattle ingested oil and gas contaminants. This inference was justified in view of the plaintiff's testimony that his cattle had access to the evacuation site, and the testimony of the plaintiff and his veterinarian concerning the propensity of cattle to drink water and lick or eat soil flavoured by chemicals.

As for Imperial's fourth ground of appeal, the majority agreed with the appellant that the plaintiff had to prove causation using the "but for" test, as opposed to the material contribution test. The majority went on to find, however, that the plaintiff proved causation to the "but for" standard, so it did not matter that the trial judge invoked the material contribution test. That is, the trial judge found that oil and gas contaminants were a significant factor in the compromised health of half of the plaintiff's herd based on evidence related to the differences between the cattle that had access to Imperial's evacuation site and those that did not. According to the majority, this finding constituted a finding of causation in accordance with the primary "but for" test. ${ }^{142}$

In his dissenting judgment, Justice Slatter would have allowed Imperial's appeal, mainly because the trial judge did not make explicit findings of fact on whether the plaintiff's cattle ingested enough oil and gas contaminants to affect their health. This matter was essential to the case, according to Justice Slatter, because without a positive finding, no conclusion could be drawn about whether Imperial's negligence or nuisance caused damage to the plaintiff's herd. Unlike the majority, Justice Slatter did not think there was enough evidence before the trial judge to justify an implicit finding the plaintiff's cattle ingested large quantities of oil and gas contaminants: first, because "no witnesses actually saw the cattle consume contaminated soil or water"; and second, because the plaintiff was the only witness who testified to seeing cattle in the vicinity of the excavation. ${ }^{143}$

In the final decision of the trilogy, Blatz, the plaintiff advanced claims in negligence, nuisance, and the rule in Rylands, alleging damage to its water supply well, the related aquifer, and water beneath lands that the plaintiff planned to develop as a residential subdivision. In early 2002, the defendant company, Impact, began drilling a sour gas well on the plaintiff's property. Impact excavated several pits on its lease site, which it used to 
store drilling by-products, including drilling mud. In the spring of 2002, the plaintiff's family noticed a change in the quality of its water supply and notified Impact. Impact hired consultants to assess the water and test results showed elevated levels of nitrates and nitrites in the water. Impact advised the Blatz family to stop drinking the well water and provided them with an alternate water supply.

Under the rule in Rylands, the plaintiff had to establish that Impact brought or kept something on its lease site that was likely to do mischief if it escaped. Justice Nation found that the plaintiff established this by showing that Impact kept drilling mud on the lease site.

Regarding the plaintiff's claim in nuisance, the trial judge simply stated, "the application of the law to the facts results in a similar finding, to the application of the Rylands v. Fletcher principles." 144 This suggests that Justice Nation viewed nuisance in the same light as the courts in Jones and Ball. That is, Impact would be strictly liable for any damage to the plaintiff's property caused by the release of a noxious substance, such as drilling mud.

As for the plaintiff's claim in negligence, the trial judge found that Impact breached the duty of care that it owed to the plaintiff by allowing contaminants to leak from their pits and lease site and contaminate the water chemistry of the plaintiff's water supply well. ${ }^{145}$ This suggests that Impact was under a duty to take all reasonable measures to protect the plaintiff's water supply.

The experts that testified for both sides in Blatz agreed that the plaintiff's well supply water was contaminated in the spring of 2002. There was also sufficient evidence to show that the well water was safe to drink before this time. Thus, the quality of the plaintiff's drinking water changed not long after Impact began storing drilling by-products in open pits on the lease site. But despite the timing of this change, the plaintiff struggled to prove causation. One reason was that the chemical composition of the drilling by-products in Impact's pits was never analyzed. ${ }^{146}$ Therefore, it was impossible to know for certain whether the drilling by-products kept on Impact's lease site contained the same kind of bacteria as that detected in the plaintiff's water well. Further, there was no direct evidence of a hydraulic connection between Impact's lease site and the plaintiff's water well. In other words, there was no way to know for certain whether contaminated water from Impact's lease site had moved into the plaintiff's well via an underground passage.

In the end, Justice Nation determined that there was sufficient evidence to infer that Impact's lease site activities caused damage to the plaintiff's water supply well in early $2002 .{ }^{147}$ However, the plaintiff failed to prove damage to the well's related aquifer, or to the water beneath lands that he planned to develop as a residential subdivision. ${ }^{148}$ The plaintiff

Supra note 119 at para 157.

Ibid at para 158.

Ibid at paras 129-30.

Ibid at para 143 .

On appeal, the plaintiff argued that the trial judge misconstrued evidence to the effect that, because other water on the plaintiff's property was contaminated, the plaintiff would have no choice but to put in place a water processing facility to proceed with its planned subdivision (i.e. to receive approval from Alberta Environmental and the Municipal District), regardless of whether water beneath the subdivision lands was itself contaminated (Blatz v Impact Energy Inc, 2011 ABCA 92 at para 14). The Court of Appeal dismissed the appeal, finding that the record did not support the proposition that Alberta Environment 
received $\$ 30,000$ for the damage to the water supply well - enough to cover the cost of repairs, or if necessary, to drill a new well. The plaintiff received an additional $\$ 7,000$ $(\$ 1,000$ for each person) for minor illnesses suffered in connection with the contaminated well water, as well as $\$ 4,000$ for lost income — that is, for the time that one family member spent away from work, dealing with well-related issues. ${ }^{149}$

In sum, Jones, Ball, and Blatz provide examples of situations in which landowners may be able to bring common law causes of action to recover damages for harms suffered by them as a result of oil and gas activities on their lands. But the cases also show that the plaintiffs face challenges in doing so, especially with respect to proof of causation. ${ }^{150}$ The next section provides a comparison of the relative challenges that a plaintiff landowner faces when proceeding under either section 30 of the $S R A$ or under a common law cause of action.

\section{A. Comparing Section 30 and Tort Causes of ACTION}

This section examines two reasons why section 30 claimants may find it easier to succeed than plaintiffs suing in the ordinary courts. The first reason is that tortious causes of action require plaintiffs to establish more elements, on a balance of probabilities, than the statutory cause of action created by section 30 . To develop this point, we look to the elements that the plaintiffs Jones, Ball, and Blatz had to establish in order to succeed using tortious causes of action that they would not have had to establish under section 30 . The second reason is that the Board takes a "less systematic" approach than the courts when considering the question of causation. As a result, section 30 claimants may be able to establish causation with less evidence than plaintiffs appearing before the courts. We develop this point by comparing the courts' approach to causation in the trilogy of cases and the Board's approach to causation in its Smith and Heidinger decisions.

\section{B. FeWER ELEMENTS TO ESTABLISH}

Each case in the trilogy of tort cases involved claims of negligence, and thus each plaintiff had to show that the defendant owed them a duty of care and breached that duty of care. Practically speaking, when the parties to a lawsuit are also parties to a surface lease or right of entry order the defendant's duty of care will rarely be an issue. ${ }^{151}$ But the breach of the duty of care is a different matter. Plaintiffs must adduce evidence of an act or omission that exposed the plaintiff to a risk of harm. This may include evidence about standard industry practice and the defendant's departure therefrom. Alternatively, as in Jones, the plaintiff may argue that a reasonable person in the defendant's position ought to have known that unless the defendant took measures to exceed standard industry practice in some crucial respect (for example, with regard to fencing), the plaintiff would be exposed to a risk of harm. Regardless of the nature of the evidence, a plaintiff in a negligence action must prove, on the balance of probabilities, that the defendant was negligent. A claimant under section 30, on the other

and the Municipal District would not approve the subdivision because the plaintiff's own water supply well had been contaminated (ibid at para 17).

Supra note 119 at para 210.

This is quite apart from the significant costs associated with bringing the matter to trial.

See e.g. Blatz, supra note 119 at para 158 where the Court stated: "In relation to the claim framed in negligence, the duty of care owed by the defendants was never in issue." 
hand, is under no obligation to show that an operator owed a duty of care or that they breached that duty by exposing the claimant to a risk of harm.

Jones, Ball, and Blatz also involved claims in nuisance, and thus each plaintiff had to show that the defendant company's conduct or land use constituted an "unreasonable interference" with the plaintiff's own use and enjoyment of land. ${ }^{152}$ There is no clear definition of unreasonable interference in private nuisance, but courts tend to regard conduct or land use as an unreasonable interference if it produces substantial discomfort to others or causes material damages to the property of others. ${ }^{153}$ This means that a plaintiff who can show that the defendant caused material damage to their land will have little difficultly establishing the element of unreasonable interference. ${ }^{154}$ Practically speaking, this type of plaintiff is in a similar position to claimants under section 30 in that the plaintiff should be able to establish the defendant's liability by proving just two elements: damage and causation.

On the other hand, when a plaintiff cannot show material damage to land, the courts will consider a number of factors in determining whether the defendant's interference with the plaintiff's land use constitutes an unreasonable interference. Courts consider whether the defendant's interference with the plaintiff's land use would offend the average person. ${ }^{155}$ Courts also consider the character of the neighborhood in which the nuisance is said to have occurred. ${ }^{156}$ Recall that section 30 claimants have been awarded damages in respect of minor damage or intangible effects on land without arguing such factors. For instance, in Gunderson, the operator was found liable because garbage was left on the claimant's land. That said, the Board has also determined, in other cases, that in the absence of material damage to land, a claimant under section $30(1)$ (a) is not entitled to damages. ${ }^{157}$

The rule in Rylands, which was argued only in Blatz, also requires a plaintiff to establish elements that an applicant does not have to establish under section 30. To succeed using the rule in Rylands, a plaintiff must prove that the defendant used its land in a "non-natural" way, and that there was an escape of a substance likely to do mischief. ${ }^{158}$ As to the first requirement, courts may consider whether the defendant used its land for the benefit of the wider community in deciding whether the land use was "non-natural." ${ }^{\text {159 }}$ With respect to the

Royal Anne Hotel v Ashcroft (Village of) (1979), 95 DLR (3d) 756 (BCCA) at 759-60.

Lewis N Klar, Tort Law, 4th ed (Toronto: Thomson Canada Limited, 2008). See reference at 727 to the judgment of Lord Chancellor Westbury in St Helen's Smelting Co v Tipping (1865), 11 HLC 642 at 650. It should be noted that the Courts in Jones, Ball, and Blatz did not discuss whether the defendant company's actions constituted unreasonable interferences with the plaintiff's use and enjoyment of land. The most probable explanation is simply that physical damage (i.e. contamination) of land and/or water was at issue in all three cases.

Klar, supra note 153 at 728, where he refers to the judgment of Lord Wright in Sedleigh-Denfield $v$ O'Callaghan, [1940] 3 All ER 349 at 364 (HL).

Sturges $v$ Bridgman (1879), 11 Ch D 852 at 865.

See e.g. Dandell, supra note 72.

Supra note 6 at 339.

See e.g. Kelliher (Village of) v Smith, [1931] SCR 672 at 682 [Smith], where a fire extinguisher exploded, and the Court held that the rule in Rylands "only applies where the dangerous agency is kept by the defendant for his own purposes. It, therefore, has no application where, as here, the extinguisher was brought to the village for the common protection of the corporation and its citizens as individuals." In Blatz, the Court did not look specifically at the question of whether defendant's land use was "nonnatural." Implicitly, the Court seems to have accepted either: a) that storing drilling by-products in open pits constitutes a non-natural use of land, or b) that a drilling a sour gas well constitutes a non-natural use of land. Supra note 119. 
"escape" requirement, a plaintiff must be able to show that the damage was caused by a substance; however, a plaintiff does not need to prove that the escaped substance was inherently dangerous, or that it was brought onto the land by the defendant. ${ }^{160}$ Neither of the Rylands requirements applies to section 30 claimants. Recovery under section 30 is never contingent on a claimant's ability to show that damage to its land or personal property was the result of an escaped substance. Nor does a claimant need to show that the operator's land use was unnatural.

In sum, section 30 claims must fit in one or more of the three heads of damages set out in section 30(1). That is, claims must relate to damaged land (to which the operator has no legal entitlement), lost or damaged personal property (including livestock), or lost time or expense. Provided that a claim fits into one or more of these heads, the claimant must establish only two elements, on a balance of probabilities: damage and causation. In contrast, common law tort causes of action including negligence, nuisance, and the rule under Rylands typically require plaintiffs to establish elements in addition to those of damage and causation before recovery is available. ${ }^{161}$ To prove one or more of these additional elements, plaintiffs must adduce evidence in relation to the "faultiness" of a defendant or the character of the defendant's use of land — that is, that the land use constituted an unreasonable interference or "non-natural" use. Section 30, on the other hand, requires claimants to formulate just one argument in relation to an operator's activities: that the operator's activities gave rise to or caused the claimant's losses.

\section{Less Systematic Approach to Finding Causation}

In comparing how courts and the Board approach the issue of causation, one obvious difference is that courts make more use of case law and precedent. While courts generally apply the standard "but for" test for causation, or in some cases consider other tests such as "material contribution," the Board does not refer to case law or previous Board decisions for guidance on causation. Nor does the Board mention using a particular test for causation, or, for that matter, deviating from a standard test. These are significant differences that could, in some cases, affect the ability of a plaintiff to recover in the ordinary courts, as compared with a claimant who advances a damages claim before the Board.

However, courts and the Board also differ in their approaches to fact-finding and evidence in questions of causation, and this discrepancy has a greater bearing on the relative abilities of plaintiffs and section 30 claimants to establish causation. In the trilogy of cases, each court took a systematic approach to finding causation. That is, the different courts addressed a number of individual questions, all of which were relevant to the broad question of whether the defendant caused damage to the plaintiff, and made findings with respect to each. In order to make findings, the court weighed relevant portions of the evidence before it.

See e.g. Chu v Dawson (1984), 18 DLR (4th) 520 (BCCA), where the defendant excavated land to build a pool, then piled the excavated soil on the lip of a ravine. The soil collapsed, years later, damaging the property below. The British Columbia Court of Appeal affirmed that the defendant was liable under the rule, though the soil was not brought onto the land from elsewhere and was not itself inherently nonnatural or dangerous, only becoming so because of the way it had been "collected."

Except where nuisance is claimed in relation to material damage to the plaintiff's property. In that case, the plaintiff will be able to prove an "unreasonable interference" using evidence that the defendant caused material damage. 
The Blatz judgment clearly demonstrates this systematic approach to causation. Before deciding the broad question of whether Impact's lease site activities damaged the plaintiff's water supply, the trial judge considered the following: whether Impact kept contaminants in open pits on its lease site; whether the pits leaked in early 2002, in the months prior to the plaintiff noticing a change in the quality of its water supply; and whether there was a hydraulic connection between the pits and the plaintiff's well including the consideration of whether it was possible for water leaving the pits to end up in the plaintiff's well. For each of these questions, the Court considered the evidence presented by both sides, noted areas of concurrence and disagreement in the evidence, and noted gaps in the evidence. The Court then drew a series of inferences. In Jones, there was direct evidence to show that the plaintiff's cattle had consumed at least some oil and gas contaminants, and thus the Court did not need to draw inferences on that question. Instead, the Court weighed evidence and addressed a series of questions about other possible causes of poor health in the plaintiff's herd, besides the ingestion of oil and contaminants.

In Ball, the trial judge's approach to causation was less systematic, and this drew strong criticism from Justice Slatter, who would have allowed Imperial's appeal on the basis that the trial judge did not make findings on questions that were essential to the broad issue of causation. The majority of the Court of Appeal in Ball, however, examined the questions relevant to the larger issue of causation (that is, three of Imperial's four grounds of appeal) and determined that in each case, there was sufficient evidence to warrant an inference favourable to the plaintiff. In other words, the majority applied the systematic approach to causation discussed above.

Ultimately, the evidence before the courts in the trilogy allowed each court to answer questions necessary for overall findings of causation. This evidence was part circumstantial and part "scientific." For instance, in Blatz, the plaintiff presented evidence on the timing of problems in its water supply well (such as the quality of the well water diminished in the months after the defendant began storing drilling mud in open pits), as well as evidence to show that the movement of underground water from the defendant's lease site to the plaintiff's water well was possible, albeit not certain. The plaintiffs in Jones and Ball presented strong circumstantial evidence in the form of comparisons. In Jones, the plaintiff contrasted its cull rate with the industry average. In Ball, the plaintiff contrasted the good health of one half of its herd to the poor health of the other half, which was exposed to defendant's lease site. As well, the plaintiffs in Jones and Ball had test results to indicate the presence of hydrocarbons in some of their livestock.

In contrast, the Board takes a less systematic approach to causation. Smith and Heidinger illustrate this point. The claimants in both cases lacked direct evidence that the operators' activities caused deaths in their herds of whitetail deer and cattle, respectively. The claimants also lacked autopsy results that could have, at the very least, suggested that the operators' activities were a possible cause of the deaths. The claimants could only point to the fact that they found livestock dead shortly after key events took place. In Smith, that key event was the operator's equipment backfiring. In Heidinger, it was when the operator started work on a pipeline. The claimant in Smith also presented evidence of the measures it took to reduce panic-induced injuries in its herd of whitetail deer, including installing electrical fencing around the deer pens to keep predators from getting too close, and selective breeding and 
culling. As well, an experienced game farmer testified on the effectiveness of the measures taken by the Smith claimant to reduce panic-induced injuries in the herd, the likelihood of whitetail deer panicking at the sound of equipment repeatedly backfiring, and the value of the two deer that died.

The Board's decisions in Smith and Heidinger do not show the Board tackling a series of questions to determine the larger question of whether the operator's activities caused the deaths of the claimant's livestock. In Smith, for example, the Board might have considered and made findings on the possibility that another sound frightened the deer before or after the operator's equipment backfired, whether the sound of the operator's equipment backfiring was sufficiently loud to frighten the deer, and the possibility that the deer died from a cause other than panic (for example, a pre-existing illness). But instead of considering these types of questions, the Board simply addressed the broad question of causation and found in the claimant's favour. The Board stated: "Absolute proof, in an instance such as this may be impossible, yet too many circumstances point too strongly towards equipment failure on the part of the Operator, being the instigating cause of the loss of the two animals." 162 The Board's decision in Heidinger is similar in that the Board did not address a series of questions before finding in the claimant's favour.

One reason the Board does not take a systematic approach to causation may be that in cases such as Smith and Heidinger, there is not enough evidence before the Board to allow for such an approach. For example, if the Board in Smith had decided to deal with the questions set out in the preceding paragraph, it likely would have struggled with the final question (on pre-existing illness in the deer) because without autopsy results the evidence on this point would probably be limited to the claimant's own opinion about the health of the deer. For some, and perhaps operators in particular, it may seem unfair that the Board does not require claimants to provide the amount of evidence necessary for it to deal with causation using the same approach as the courts. But the Board seems to see the issue from the other side - that it would be unfair to require claimants to incur too much expense in order to recover under section 30. For example, in Heidinger, the Board stated: "It is understandable why Shirley Heidinger did not have an autopsy done as it would have meant more costs. With increased costs this year to farmers and ranchers caused by the drought, the Heidingers felt they could not afford to do this, but rather told the Operator they could have an autopsy done if they wished. The Operator chose not to." 163

In Smith, the Board viewed the claimant's failure to obtain autopsy results with less sympathy: "The climate in Central Alberta, in late October, would not, in the Board's opinion, have precluded Mr. Smith from covering and storing the carcasses, long enough and in good enough condition for an autopsy to have been conducted. This would at least have provided evidence as to the cause of death if not what brought about the "cause.",164

Nevertheless, the Board in Smith did not consider the claimant's failure to obtain autopsy results as a sufficient reason to prohibit all recovery. The Board awarded the claimant half of the amount it claimed in respect of the two deer, and stated: 
The Board is aware of and sympathetic to its past history of not awarding damage claims without strong evidence pointing to the cause of the damage. Energy companies must be protected from being held hostage, for misfortunes or mismanagement, not of their doing and beyond their control.... While a landowner should not be enriched, or compensated for losses which cannot be reasonably traced to the Operator's presence, neither should he have to labour under an excessive or unreasonable burden of proof. ${ }^{165}$

Thus, owners and occupants may find it easier to establish causation before the Board than if they were proceeding in the ordinary courts. ${ }^{166}$ But much will depend upon the operator and the evidence that is available. If the operator offers a credible alternative explanation of the loss or damage the Board will need to proceed more carefully. If the only evidence on the record before the Board is that of the owner, so long as that record provides some basis on which the Board can find or infer causation, that will be enough. One of the differences between Board and court proceedings may simply be that operators are less inclined to mount aggressive and expensive challenges to an owner's theory of causation in matters before the Board than they would be in the courts. ${ }^{167}$

The trilogy plaintiffs did not have the option of making a claim under section 30 since in all three cases, the value of the claims exceeded $\$ 25,000$. But if we ignore the dollar cap on section 30 awards and assume there were no facts that would limit the Board's jurisdiction, for the reasons set out above, it seems likely that the trilogy plaintiffs would have been able to establish the liability of the defendants more easily had their claims been heard by the Board rather than by the ordinary courts. Further, the three heads of damages under section 30(1) makes damages available for most of the types of loss experienced by the trilogy plaintiffs. Section 30(1)(a) makes damages available for the Blatz plaintiff's water supply well (that is, as damaged land). The plaintiffs in Jones and Ball could claim losses in respect of their livestock under section 30(1)(b). The third and final head of section 30 makes damages available for time spent and expense incurred in recovering livestock. At first glance, this heading does not seem to apply to the claims advanced in Jones, Ball, and Blatz, given that the cases do not involve stray animals. However, it should be recalled that the Board often awards damages to owners and occupants who have lost time in other ways, for example, in monitoring livestock, as in Gunderson, or in dealing with the operator following an incident, as in Miller. This raises the possibility that the plaintiffs in Jones and Ball could

Ibid at 5 .

Smith and Heidinger show that section 30 claimants may be able to establish causation with less evidence than would likely be required by the ordinary courts. However, in other decisions the Board determined that there was insufficient evidence to find causation. Claims for lost livestock failed in each of the following cases, and in each case the Board indicated that the claimant's chances of recovery would have been greater had expert opinions or autopsies been obtained: Allied Oil \& Gas Corp v Imbeault, SRB Decision 2001/0222 (13 December 2002); Canadian Natural Resources Ltd v Leppky, SRB Decision 2005/0095 (29 August 2005); Dayment, supra note 106.

167 There may be various reasons for this. One might be the concern for the adverse publicity that may flow from losing a court case which may be portrayed more generally as landowner versus the oil and gas industry. Another reason may be that an operator may be reserving the "big guns" for an appeal. An appeal from a Board decision takes the form of a new hearing where new evidence can be led. However, there are risks associated with not mounting a complete defence before the Board given the deference shown by courts on appeal. See Imperial Oil v Smulski (1981), 18 Alta LR (2d) 200, where the Court of Appeal restored a compensation order rendered by the Board. In his concurring decision, Justice McClung objected to operators deferring the presentation of evidence until a Board decision is appealed to the Court of Queen's Bench. He wrote that such a practice is not in keeping with the legislative objective of the SRA and added (ibid at 203): "Evidence which is not presented at the first opportunity and from a convenient source should be approached with caution. The ends of the Surface Rights Act are not promoted by inverting the board's assessment into a mere stalking horse or provisional inquiry which lends itself to easy adjustment under the guise of the statutory appeal." 
use section 30(1)(b), or section 30 generally, to recover damages for extra time spent dealing with sick animals (in both cases the courts awarded General Damages for this loss). It also raises the possibility of the plaintiff in Blatz receiving damages for time spent dealing with the operator (the Court awarded \$4,000). Finally, in Blatz, the Court awarded damages for the illnesses experienced by family members after drinking contaminated well water. It is questionable whether a plaintiff would have been able to recover this loss, in respect of personal injury, under any of the three heads of section 30(1). Thus far, no claims for personal injury appear to have been advanced under section 30 .

\section{Conclusion}

In this article we have examined the background to the Board's damages jurisdiction under section 30 of the $S R A$, and we have examined the Board's practice and jurisprudence under this $S R A$ provision. This section provides owners and occupiers with an alternative statutory cause of action to owners and occupiers who suffer damage as a result of oil and gas and other operations on their lands. This statutory cause of action does not remove the possibility that an owner or occupier may bring a tort action in the common law courts to recover losses due to oil and gas operations on their property, but in many cases, such an action will simply not be a viable option. The amount of damage sustained by an individual may not justify the time and expense of a lawsuit, particularly if testimony and expert opinions are required to establish a causative link between the damage and the activities of the operator. In such a case, an owner or occupant will risk spending the equivalent (or more) in legal fees and expert fees than the amount they might recover in damages. In these cases section 30 of the $S R A$ provides an alternative cause of action and an alternative forum. Both the cause of action and the forum present the owner or occupier with fewer obstacles to recovery than a plaintiff suing in court both in terms of the elements of the cause of action and the issue of causation. 
APPENDIX A:

SUMMARIES OF BOARD DECISIONS UNDER SECTION 30 OF THE SRA, 2001-2010

\begin{tabular}{|c|r|r|r|}
\hline Year & $\begin{array}{c}\text { Number of Section 30 } \\
\text { Decisions** }\end{array}$ & $\begin{array}{c}\text { Annual Amount } \\
\text { Claimed *** }\end{array}$ & $\begin{array}{c}\text { Annual Amount } \\
\text { Awarded }\end{array}$ \\
\hline $2001^{*}$ & 7 & $\$ 63,450.75$ & $\$ 29,691.00$ \\
\hline 2002 & 7 & $\$ 69,536.06$ & $\$ 40,552.29$ \\
\hline 2003 & 7 & $\$ 86,340.57$ & $\$ 18,173.00$ \\
\hline 2004 & 5 & $\$ 1,249.50$ & $\$ 8,925.00$ \\
\hline 2005 & 7 & $\$ 89,08,500.05$ & $\$ 9,341.80$ \\
\hline 2006 & 6 & $\$ 127,608.26$ & $\$ 58,141.51$ \\
\hline 2007 & 5 & $\$ 65,035.00$ & $\$ 22,453.00$ \\
\hline 2008 & 5 & $\$ 61,819.50$ & $\$ 22,735.44$ \\
\hline 2009 & 6 & $\$ 110,316.38$ & $\$ 11,260.00$ \\
\hline 2010 & & &
\end{tabular}

*Note that the cap on section 30 damages was $\$ 5,000$ for part of 2001 .

**Number of decisions posted on the Board's website deciding section 30 damages claims — the Board may receive more claims.

*** Some decisions do not disclose the amount sought by the claimant. In cases where the decisions do not state a claimed amount and the Board awarded damages, the claimed amount is taken to be the amount awarded by the Board. This is signified by a "?" preceding the amount claimed. The assumption is problematic as the actual amount claimed probably exceeds the award.

\section{Section 30 Decisions: 2001 - 2010}

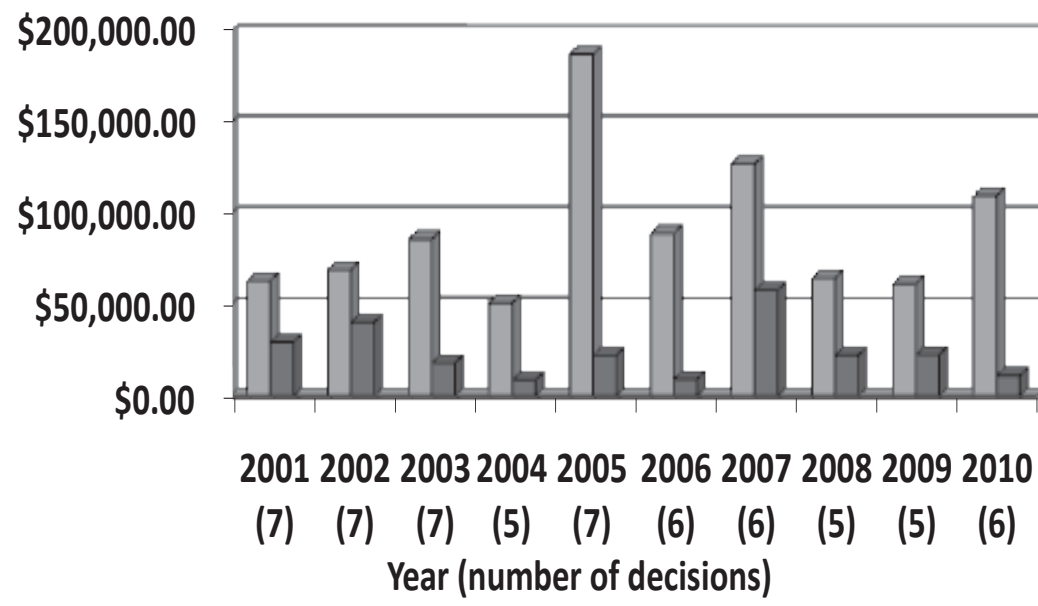

$\square$ Amount

Claimed

Amount

Awarded 


\begin{tabular}{|c|c|c|c|}
\hline $\begin{array}{l}\text { Decision } \\
\text { Number }\end{array}$ & Alleged damage & Claimed Amount & Amount Awarded \\
\hline $2001 / 0024$ & Crushed culvert, crop loss & $\$ 5,000.00$ & $\$ 2,000.00$ \\
\hline $2001 / 0102$ & Delayed seeding, crop loss & $\$ 5,000.00$ & $\$ 500.00$ \\
\hline $2001 / 0104$ & Flooding & $\$ 5,000.00$ & $\$ 0$ \\
\hline $2001 / 0128$ & Undesirable tree growth & Not disclosed & $\$ 0$ \\
\hline $2001 / 0153$ & Reclamation work done off-lease & $\$ 2,000.00$ & $\$ 600.00$ \\
\hline $\begin{array}{l}2001 / 0203 \\
\text { (three files) }\end{array}$ & $\begin{array}{l}\text { Operator used additional lands } \\
\text { during pipeline construction }\end{array}$ & $\$ 44,250.75$ & $\$ 26,291.00$ \\
\hline \multirow[t]{2}{*}{$2001 / 0222$} & $\begin{array}{l}\text { Cow fell in operator's trench, } \\
\text { climbed out and then died }\end{array}$ & $\$ 2,200.00$ & $\$ 300.00$ \\
\hline & & $\begin{array}{l}\text { Total Amount Claimed in } \\
\text { Board Decisions from } \\
\text { 2001: } \$ 63,450.75\end{array}$ & $\begin{array}{l}\text { Total Amount } \\
\text { Awarded in Board } \\
\text { Decisions from 2001: } \\
\$ 29,691.00 \\
\end{array}$ \\
\hline $2002 / 0028$ & $\begin{array}{l}\text { Spills of hazardous substance - } \\
\text { damage to cows and fish in pond }\end{array}$ & $\$ 3894.87$ & $\$ 2,000.00$ \\
\hline $2002 / 0040$ & $\begin{array}{l}\text { Operator's failure to build fence, } \\
\text { cost of constructing dug-out so } \\
\text { cattle can pasture on remaining } \\
\text { land }\end{array}$ & $\$ 46,619.30(\$ 25,000.00)$ & $\$ 4,000.00$ \\
\hline $2002 / 0044$ & $\begin{array}{l}\text { New fencing required around } \\
\text { sump pit, cow died in pit }\end{array}$ & $\$ 3,000.60$ & $\$ 2,550.00$ \\
\hline $2002 / 0065$ & $\begin{array}{l}\text { Weeds spread to land from well } \\
\text { site }\end{array}$ & $?(\$ 1,490.00)$ & $\$ 1,490.00$ \\
\hline $2002 / 0067$ & & & $\begin{array}{l}\text { Board said it lacked } \\
\text { jurisdiction because } \\
\text { claim dealt with } \\
\text { geophysical exploration }\end{array}$ \\
\hline $2002 / 0121$ & $\begin{array}{l}\text { Crop loss from pipeline } \\
\text { construction }\end{array}$ & $\$ 756.19$ & $\$ 756.19$ \\
\hline $2002 / 0247$ & $\begin{array}{l}\text { Loss of trees, clay pushed onto } \\
\text { claimant's land }\end{array}$ & $\$ 7,169.00$ & $\$ 150.00$ \\
\hline \multirow[t]{2}{*}{$2002 / 0248$} & Cows died from dust pneumonia & $\$ 6,606.10$ & $\$ 6,606.10$ \\
\hline & & $\begin{array}{l}\text { Total Amount Claimed in } \\
\text { Board Decisions from } \\
\text { 2002: } \$ 69,536.06\end{array}$ & $\begin{array}{l}\text { Total Amount } \\
\text { Awarded in Board } \\
\text { Decisions from 2002: } \\
\$ 40,552.29\end{array}$ \\
\hline $2003 / 0001$ & $\begin{array}{l}\text { Rutting caused by driving off- } \\
\text { lease }\end{array}$ & $\$ 2,000.00$ & $\$ 135.00$ \\
\hline $2003 / 0017$ & $\begin{array}{l}\text { Damage to farm equipment, } \\
\text { damage to hayfield from pipeline } \\
\text { construction }\end{array}$ & $\$ 12,106.00$ & $\$ 3,875.00$ \\
\hline $2003 / 0038$ & $\begin{array}{l}\text { Damage to irrigation system, crop } \\
\text { loss from flooding }\end{array}$ & $\$ 24,392.70$ & $\$ 0$ \\
\hline
\end{tabular}




\begin{tabular}{|c|c|c|c|}
\hline $\begin{array}{l}\text { Decision } \\
\text { Number }\end{array}$ & Alleged damage & Claimed Amount & Amount Awarded \\
\hline $2003 / 0043$ & $\begin{array}{l}\text { Damage to trees, ground } \\
\text { disturbance caused by vandalism }\end{array}$ & $\$ 11,000.00$ & $\$ 4,000.00$ \\
\hline $\begin{array}{l}\text { 2003/0044 } \\
\text { (three files) }\end{array}$ & Loss of grazing land & $\$ 6,499.71$ & $\$ 5,613.00$ \\
\hline $2003 / 0057$ & Trespass & $\$ 14,092.16$ & $\$ 3,400.00$ \\
\hline \multirow[t]{2}{*}{$2003 / 0137$} & Trespass, crop loss & $\$ 16,250.00$ & $\$ 1,150.00$ \\
\hline & & $\begin{array}{l}\text { Total Amount Claimed in } \\
\text { Board Decisions from } \\
\text { 2003: } \\
\$ 86,340.57\end{array}$ & $\begin{array}{l}\text { Total Amount } \\
\text { Awarded in Board } \\
\text { Decisions from 2003: } \\
\$ 18,173.00\end{array}$ \\
\hline $2004 / 0014$ & Flooding of pasture & Not disclosed & $\$ 0$ \\
\hline $2004 / 0078$ & Pipeline rupture & $\$ 7,000.00$ & $\$ 5,000.00$ \\
\hline $2004 / 0079$ & Calf escaped - hit by car & $\$ 800.00$ & $\$ 800.00$ \\
\hline $2004 / 0081$ & $\begin{array}{l}\text { Rutting and erosion caused by } \\
\text { trespass }\end{array}$ & $\$ 2,345.00$ & $\$ 2,345.00$ \\
\hline \multirow[t]{2}{*}{$\begin{array}{l}2004 / 0082 \\
\text { (five files) }\end{array}$} & $\begin{array}{l}\text { Closing gates, rounding up of } \\
\text { cattle, dealing with operator and } \\
\text { others }\end{array}$ & $\$ 41,104.50$ & $\$ 780.00$ \\
\hline & & $\begin{array}{l}\text { Total Amount Claimed in } \\
\text { Board Decisions from } \\
\text { 2004: } \\
\$ 51,249.50\end{array}$ & $\begin{array}{l}\text { Total Amount } \\
\text { Awarded in Board } \\
\text { Decisions from 2004: } \\
\$ 8,925.00\end{array}$ \\
\hline $2005 / 0134$ & Rock damage to mower & $\$ 2,075.74$ & $\$ 0$ \\
\hline 2005/0999 & $\begin{array}{l}\text { Crop loss due to salt water } \\
\text { sprayed from well }\end{array}$ & $\$ 10,725.00$ & $\$ 10,225.00$ \\
\hline $2005 / 0095$ & 26 dead buffalo - anthrax & $\$ 25,000.00$ & $\$ 0$ \\
\hline $2005 / 0082$ & Soil erosion & $\$ 25,000.00$ & $\$ 0$ \\
\hline $2005 / 0076$ & Contaminated land from well & $\$ 6,192.00$ & $\$ 6,192.00$ \\
\hline $\begin{array}{l}\text { 2005/0028 } \\
\text { (three files) }\end{array}$ & $\begin{array}{l}\text { Crop loss, loss of grazing, loss of } \\
\text { access (operator failed to backfill } \\
\text { trench) }\end{array}$ & $\$ 60,091.99$ & $\$ 0$ \\
\hline \multirow[t]{2}{*}{$\begin{array}{l}2005 / 0003 \\
\text { (three files) }\end{array}$} & $\begin{array}{l}\text { Soil erosion downwind from well } \\
\text { site and access road }\end{array}$ & $\begin{array}{l}\$ 59,000.00 \text { (not entirely } \\
\text { clear from the decision) }\end{array}$ & $\$ 5,974.80$ \\
\hline & & $\begin{array}{l}\text { Total Amount Claimed in } \\
\text { Board Decisions from } \\
\text { 2005: } \$ 188,084.73\end{array}$ & $\begin{array}{l}\text { Total Amount } \\
\text { Awarded in Board } \\
\text { Decisions from 2005: } \\
\$ 22,391.80\end{array}$ \\
\hline $2006 / 0004$ & $\begin{array}{l}\text { Contamination of remaining } \\
\text { lands/water, trespass }\end{array}$ & $\$ 19,750.00$ & $\$ 300.00$ (for trespass) \\
\hline $2006 / 0075$ & Damage to haybine, escaped cattle & $\begin{array}{l}\$ 9,526.74 \text { (includes some } \\
\text { costs) }\end{array}$ & $\$ 0$ \\
\hline $2006 / 0118$ & Trespass, surveillance of gates & $\$ 8,760.00$ & $\$ 0$ \\
\hline $2006 / 0119$ & $\begin{array}{l}\text { Trespass - misplaced access road } \\
\text { caused rutting }\end{array}$ & $\$ 12,864.11$ & $\$ 1,728.50$ \\
\hline
\end{tabular}




\begin{tabular}{|c|c|c|c|}
\hline $\begin{array}{l}\text { Decision } \\
\text { Number }\end{array}$ & Alleged damage & Claimed Amount & Amount Awarded \\
\hline $2006 / 0139$ & Pesticide applications & $\$ 13,599.20$ & $\$ 0$ \\
\hline \multirow[t]{2}{*}{ 2006/0159 } & $\mathrm{H}_{2} \mathrm{~S}$ release affecting bull fertility & $\$ 25,000.00$ & $\begin{array}{l}\$ 7,316.90 \text { (operator } \\
\text { previously offered to } \\
\text { pay this amount for } \\
\text { animal testing, } \\
\text { transportation, and } \\
\text { inconvenience) }\end{array}$ \\
\hline & & $\begin{array}{l}\text { Total Amount Claimed in } \\
\text { Board Decisions from } \\
\text { 2006: } \$ 89,500.05\end{array}$ & $\begin{array}{l}\text { Total Amount } \\
\text { Awarded in Board } \\
\text { Decisions from 2006: } \\
\$ 9,345.40\end{array}$ \\
\hline $2007 / 0039$ & $\begin{array}{l}\text { Fence resulted in crop loss, extra } \\
\text { farming expenses, costs of feeding } \\
\text { cattle during pipeline } \\
\text { construction, meeting with } \\
\text { operator }\end{array}$ & $\$ 2,728.26$ & $\$ 541.51$ \\
\hline $2007 / 0040$ & Damaged land & $\$ 15,880.00$ & $\$ 0$ \\
\hline $2007 / 0070$ & $\begin{array}{l}\text { Damage to land (inferior soil used } \\
\text { to reclaim a borrow pit) }\end{array}$ & $\$ 21,000.00$ & $\begin{array}{l}\$ 0 \text { - Claimant already } \\
\text { accepted } \$ 5000.00 \\
\text { settlement; no additional } \\
\text { damage }\end{array}$ \\
\hline $2007 / 0071$ & $\begin{array}{l}\text { Access road not reclaimed, calves } \\
\text { cut off from pasture, damaged } \\
\text { fence }\end{array}$ & $\$ 25,000.00$ & $\begin{array}{l}\$ 0-\text { Claimant already } \\
\text { accepted } \$ 23,000.00 \\
\text { settlement; no additional } \\
\text { damage }\end{array}$ \\
\hline $2007 / 0129$ & Unauthorized trespass & $\$ 6,000.00$ & $\$ 600.00$ \\
\hline \multirow[t]{2}{*}{$2007 / 0153$} & $\begin{array}{l}\text { Decision regarding three } \\
\text { files/separate damage claims: } \\
\text { 1. crop loss due to oil spill } \\
\text { 2. top soil loss and weed control } \\
\text { 3. top soil loss, water damage due } \\
\text { to run-off patterns being disturbed } \\
\text { and weed control }\end{array}$ & $\begin{array}{l}\text { Claim 1: } \$ 7000.00 \\
\text { Claim 2: } \$ 25,000.00 \\
\text { Claim 3: } \$ 25,000.00\end{array}$ & $\begin{array}{l}\text { Full amount awarded } \\
\text { for all three claims }\end{array}$ \\
\hline & & $\begin{array}{l}\text { Total Amount Claimed in } \\
\text { Board Decisions from } \\
\text { 2007: } \$ 127,608.26\end{array}$ & $\begin{array}{l}\text { Total Amount } \\
\text { Awarded in Board } \\
\text { Decisions from 2007: } \\
\mathbf{\$ 5 8 , 1 4 1 . 5 1} \\
\end{array}$ \\
\hline $2008 / 0027$ & Driving off-lease & $\$ 6,245.00$ & $\$ 8,271.00$ \\
\hline $2008 / 0062$ & $\begin{array}{l}\text { Rig worker camping, taking down } \\
\text { fence line }\end{array}$ & $\$ 15,000.00$ & $\$ 4,200.00$ \\
\hline $2008 / 0078$ & Lost tress; trespass & $\$ 25,000.00$ & $\$ 0$ \\
\hline $2008 / 0158$ & Dead deer & $\$ 10,000.00$ & $\$ 5000.00$ \\
\hline $2008 / 0165$ & $\begin{array}{l}\text { Unable to pasture livestock, } \\
\text { inadequate fencing around well } \\
\text { site }\end{array}$ & $\$ 8,790.00$ & $\$ 4,982.00$ \\
\hline
\end{tabular}




\begin{tabular}{|c|c|c|c|}
\hline Decision & Alleged damage & Claimed Amount & Amount Awarded \\
\hline & & $\begin{array}{l}\text { Total Amount Claimed in } \\
\text { Board Decisions from } \\
\text { 2008: } \$ 65,035.00\end{array}$ & $\begin{array}{l}\text { Total Amount } \\
\text { Awarded in Board } \\
\text { Decisions from 2008: } \\
\$ 22,453.00\end{array}$ \\
\hline $2009 / 0051$ & $\begin{array}{l}\text { Rutting caused by driving off- } \\
\text { lease }\end{array}$ & $\$ 2,000.00$ & $\$ 0$ \\
\hline $2009 / 0070$ & $\begin{array}{l}\text { Cattle in poor health due to oil } \\
\text { and gas contaminants }\end{array}$ & $\$ 24,780.00$ & $\$ 0$ \\
\hline $2009 / 0202$ & Calves fell in pit & $\$ 24,339.50$ & $\$ 20,935.44$ \\
\hline $2009 / 0280$ & Operator cut trees & $\$ 9,000.00$ & $\$ 100.00$ \\
\hline \multirow[t]{2}{*}{$2009 / 0461$} & $\begin{array}{l}\text { Off-site damages caused by } \\
\text { efforts of Orphan Well } \\
\text { Association }\end{array}$ & $\$ 1,700.00$ & $\$ 1,700.00$ \\
\hline & & $\begin{array}{l}\text { Total Amount Claimed in } \\
\text { Board Decisions from } \\
\text { 2009: } \$ 61,819.50\end{array}$ & $\begin{array}{l}\text { Total Amount } \\
\text { Awarded in Board } \\
\text { Decisions from 2009: } \\
\$ 22,735.44\end{array}$ \\
\hline $2010 / 0185$ & $\begin{array}{l}\text { Fluid from well escaped onto } \\
\text { pasture land }\end{array}$ & $\$ 3,951.41$ & $\$ 500.00$ \\
\hline $2010 / 0243$ & $\begin{array}{l}\text { Operator did not repair fence after } \\
\text { constructing well site }\end{array}$ & $\$ 25,000.00$ & $\$ 5,000.00$ \\
\hline $2010 / 0247$ & $\begin{array}{l}\text { Chemicals sprayed or drifted onto } \\
\text { canola crop }\end{array}$ & $\$ 6,364.97$ & $\$ 2,960.00$ \\
\hline $2010 / 0338$ & $\begin{array}{l}\text { Operator drove off right-of-way } \\
\text { — caused rutting, crop loss, etc. }\end{array}$ & $\$ 25,000.00$ & $\$ 2,800.00$ \\
\hline $2010 / 0500$ & $\begin{array}{l}\text { Damage from geophysical } \\
\text { operation }\end{array}$ & $\$ 25,000.00$ & $\begin{array}{l}\$ 0 \\
\text { Board concluded it } \\
\text { lacked jurisdiction }\end{array}$ \\
\hline \multirow[t]{2}{*}{$2010 / 0679$} & Not disclosed & $\$ 25,000.00$ & $\begin{array}{l}\text { \$0 } \\
\text { Board concluded it } \\
\text { lacked jurisdiction; } \\
\text { application filed out of } \\
\text { time and damage was } \\
\text { inside surface } \\
\text { lease/right-of-way }\end{array}$ \\
\hline & & $\begin{array}{l}\text { Total Amount Claimed in } \\
\text { Board Decisions from } \\
\text { 2010: } \$ 110,316.38\end{array}$ & $\begin{array}{l}\text { Total Amount } \\
\text { Awarded in Board } \\
\text { Decisions from 2010: } \\
\$ 11,260.00\end{array}$ \\
\hline
\end{tabular}

